\title{
Use of Electrocoagulation for Treatment of Pharmaceutical Compounds in Water/Wastewater: A Review Exploring Opportunities and Challenges
}

\author{
Rahat Alam ${ }^{1, *}$, Mohd Sheob ${ }^{1}{ }^{(}$, Bilal Saeed ${ }^{1}$, Saif Ullah Khan ${ }^{1, *}{ }^{+}$, Maryam Shirinkar ${ }^{2}$, Zacharias Frontistis ${ }^{3}$, \\ Farrukh Basheer ${ }^{1}$ and Izharul Haq Farooqi ${ }^{1}$ \\ 1 Department of Civil Engineering, Zakir Husain College of Engineering \& Technology, Aligarh Muslim \\ University, Aligarh 202001, India; shoebelahi@gmail.com (M.S.); bilalsaeed8439@gmail.com (B.S.); \\ farrukhbasheer.cv@amu.ac.in (F.B.); farooqi_izhar@yahoo.com (I.H.F.) \\ 2 Department of Chemical Engineering, North Tehran Branch, Islamic Azad University, \\ Tehran 1651153311, Iran; ma.shirinkar@gmail.com \\ 3 Department of Chemical Engineering, University of Western Macedonia, GR-50132 Kozani, Greece; \\ zfrontistis@uowm.gr \\ * Correspondence: rahatalam63@gmail.com (R.A.); saifkhan@zhcet.ac.in (S.U.K.)
}

check for updates

Citation: Alam, R.; Sheob, M.; Saeed, B.; Khan, S.U.; Shirinkar, M.;

Frontistis, Z.; Basheer, F.; Farooqi, I.H. Use of Electrocoagulation for Treatment of Pharmaceutical Compounds in Water/Wastewater: A Review Exploring Opportunities and Challenges. Water 2021, 13, 2105. https://doi.org/10.3390/w13152105

Academic Editor: Antonio Zuorro

Received: 27 May 2021

Accepted: 24 July 2021

Published: 31 July 2021

Publisher's Note: MDPI stays neutral with regard to jurisdictional claims in published maps and institutional affiliations.

Copyright: (C) 2021 by the authors Licensee MDPI, Basel, Switzerland. This article is an open access article distributed under the terms and conditions of the Creative Commons Attribution (CC BY) license (https:// creativecommons.org/licenses/by/ $4.0 /)$.

\begin{abstract}
Increasing dependency on pharmaceutical compounds including antibiotics, analgesics, antidepressants, and other drugs has threatened the environment as well as human health. Their occurrence, transformation, and fate in the environment are causing significant concerns. Several existing treatment technologies are there with their pros and cons for the treatment of pharmaceutical wastewater (PWW). Still, electrocoagulation is considered as the modern and decisive technology for treatment. In the EC process, utilizing electricity (AC/DC) and electrodes, contaminants become coagulated with the metal hydroxide and are separated by co-precipitation. The main mechanism is charge neutralization and adsorption of contaminants on the generated flocs. The range of parameters affects the EC process and is directly related to the removal efficiency and its overall operational cost. This process only could be scaled up on the industrial level if process parameters become optimized and energy consumption is reduced. Unfortunately, the removal mechanism of particular pharmaceuticals and complex physiochemical phenomena involved in this process are not fully understood. For this reason, further research and reviews are required to fill the knowledge gap. This review discusses the use of EC for removing pharmaceuticals and focuses on removal mechanism and process parameters, the cost assessment, and the challenges involved in mitigation.
\end{abstract}

Keywords: remediation; pharmaceuticals; polyaromatics; electrocoagulation; co-precipitation; optimisation

\section{Introduction}

Pharmaceuticals compounds have now become a necessary component of a sophisticated lifestyle in many ways. Every day, we extensively use pharmaceuticals such as antibiotics, hormones, analgesics, and antidepressants. The presence of these contaminants in the environment either directly or due to their metabolites/after chemical modifications are very toxic. In the last decade, the detection of several groups of antibiotics such as Norfloxacin, Ciprofloxacin, Clarithromycin, Ofloxacin, Levofloxacin, and Oxytetracycline in the environment has imposed anxiety on researchers [1,2]. Even they are present in drinking water in varying concentrations $[3,4]$. These common pharmaceuticals can easily enter into water bodies via drug manufacturing companies [5], hospitals [6], medical waste, and prescribed consumption of different medicines. These pharmaceuticals upon consumption are partially metabolized by the human body and are mainly discharged through urine and faeces [7].

Wastewater from pharmaceutical companies is associated with a high amount of COD and nitrogenous compounds that need additional treatment. Discharging such effluent into 
a nearby environment without proper treatment can cause a detrimental effect on flora and fauna [8]. The presence of a high concentration of oestrogen could enhance the mortality rate of a fish [9] and the feminization of male fish [10]. They also have an adverse effect on the human body. The long-term exposure of some complex pharmaceutical compounds present in water bodies may cause chronic as well as acute contamination [11,12], behavioural changes [13], reproductive harm [14], and cell proliferation inhibition [15]. These effluents further create microbial hazards [16,17], chemical hazards [18], and agricultural implications by entering into the food chain $[19,20]$.

Pharmaceutical wastewater includes different chemical compounds and functional groups, which inhibit microbial activity [21,22]. This characteristic makes it unfit for biological treatment. Therefore, major treatment methods for pharmaceutical wastewater are based on physio-chemical treatment. Unfortunately, the high cost of the physiochemical process makes it less popular for pharmaceutical wastewater [23]. Thus, optimized treatment by electrocoagulation process is comparatively less costly [24]. The benefit of using an EC method is that the dissolute metal hydroxides ions eliminate the inorganic contaminant present in wastewater [25-27].

Even after going through recent existing literature on pharmaceutical removal via $\mathrm{EC}$, the removal mechanism of particular pharmaceuticals and complex physiochemical phenomena involved in the process is not fully understood. In this review paper, the removal of the pharmaceutical compounds from water/wastewater via EC and their mechanisms are proposed discussed. The potential sources and different characteristics of PWW are reviewed. Additionally, their efficiencies on various operating parameters, integrated EC approach, techno-economic analysis, and opportunities and future challenges associated are discussed. In addition, the problems and mitigations in EC scale-up, software aided optimization, and different integrated EC techniques are summarized.

\section{Sources and Characteristics of Pharmaceuticals in Wastewater}

Pharmaceutical compounds enter the water bodies from several scattered sources. Pharmaceutical production companies, wastewater treatment plants, hospitals, landfills, and even graveyards are some of the main sources of contamination [28].

\subsection{Pharmaceutical Production Companies}

Pharmaceutical companies produced many types of medicines and cosmetics, including antibiotics, polyaromatics, and phenols [29]. Additionally, they discharge microplastics, gene-altering substances, and endocrine disruptors, threatening human health [30]. According to a study [31], pharmaceutical companies in Hyderabad, India, failed to treat discharged contaminants properly. As a result, a high level of antibiotic and antifungal drug residue was found in nearby water bodies [32-34]. However, a recent draft bill published on 23 January 2020 by the Indian Government limits the antibiotic concentration present in discarded waste by pharmaceutical companies [35].

\subsection{Wastewater Treatment Plants}

Pharmaceutical compounds eventually meet industrial/municipal wastewater from different sources and are collected at a nearby wastewater treatment plant. The most probable entry point of pharmaceuticals in the environment is the municipal wastewater treatment plant effluent. The human body partially metabolizes pharmaceuticals; therefore, after excretion, they are collected in the wastewater treatment plant $[7,36]$. Here, by conventional water treatment, including biodegradation and adoption, the pharmaceutical compounds remain in the effluent or concentrated on the sludge in a significant concentration [37-39]. 


\subsection{Hospitals}

Hospitals are the nucleus of pharmaceutical activities. A various range of drugs is found in the hospital wastewater. According to the study of Zhang et al. (2016), hospital wastewater contains a higher concentration of central nervous system drugs such as sulpiride and clozapine [40]. It is also seen that there is a strong correlation of pharmaceuticals in hospital waste to the population density, economy, and consumption rate [41].

\subsection{Landfills}

Waste from hospitals and pharmaceutical companies are generally disposed of in engineered landfills. However, still, there are chances of escape of these contaminants when concentrated landfill leachates reach groundwater. In the study conducted by Zhang et al. (2016) [40], the authors reported the presence of chloramphenicol, which was used in typhoid treatment, in the landfill leachate, livestock excrement, and aquaculture water [42].

\subsection{Characteristic of Wastewater Associated with Pharmaceutical Industry}

The characteristic of PWW depends on the types of prevalent drugs found in PWW. Petrovic et al. (2009) [43] reviewed different samples of PWW from different sources and gave an overview of prevalent drugs found in PWW. It is shown in Table 1.

Table 1. Prevalent drugs in PWW.

\begin{tabular}{ccc}
\hline Drugs & Chemical Class & Pharmacological Class \\
\hline Citalopram & SSRIs & Antidepressant \\
Cocaine & Tropane alkaloid & CNS stimulant/narcotic \\
Ibuprofen & Propionic acid derivative & NSAIDs \\
Propranolol & Beta blocker & Antihypertensive \\
Clotrimazole & Imidazoles & Antifungal \\
Diclofenac & Acetic acid derivative & NSAIDs \\
Metoprolol & Beta blocker & Antihypertensive \\
Indomethacin & Indole derivative & NSAIDs \\
Atenolol & Beta blocker & Antihypertensive \\
Paracetamol & Para-aminophenol derivative & NSAIDs \\
Ranitidine & H2 receptor blocker & Antihistaminic \\
Gemfibrozil & Fibric acid derivative & Lipid and cholesterol \\
Sulfadiazine & Sulfonamide & regulating \\
Clofibric acid & Antibiotic \\
Norfloxacin & Clofibrate metabolite & Lipid and cholesterol \\
Carbamazepine & Fluoroquinolone & regulating \\
Amoxicillin & Tricyclic anti-depressant & Psychiatric/Anticonvulsant \\
sulfamethoxazole & Penicillin & Antibiotic \\
Chloramphenicol & Sulfonamide & Antibiotic \\
Ofloxacin & Amphenicol-class & Antibiotic \\
Trimethoprim & antibacterial & Antibiotic \\
Ciprofloxacin & Fluoroquinolone & Antibiotic \\
Fibrates & Aminopyrimidine & Antibiotic \\
\hline & Fluoroquinolone & Blood and lipid regulating \\
\hline & Amphipathic carboxylic acid &
\end{tabular}

Wastewater characterization is necessary to select the appropriate processing method [44]. However, often, pharmaceutical effluents contain a variety of chemicals, including carcinogenic, mutagenic, and others. All possible pollutants are classified in Figure 1. 


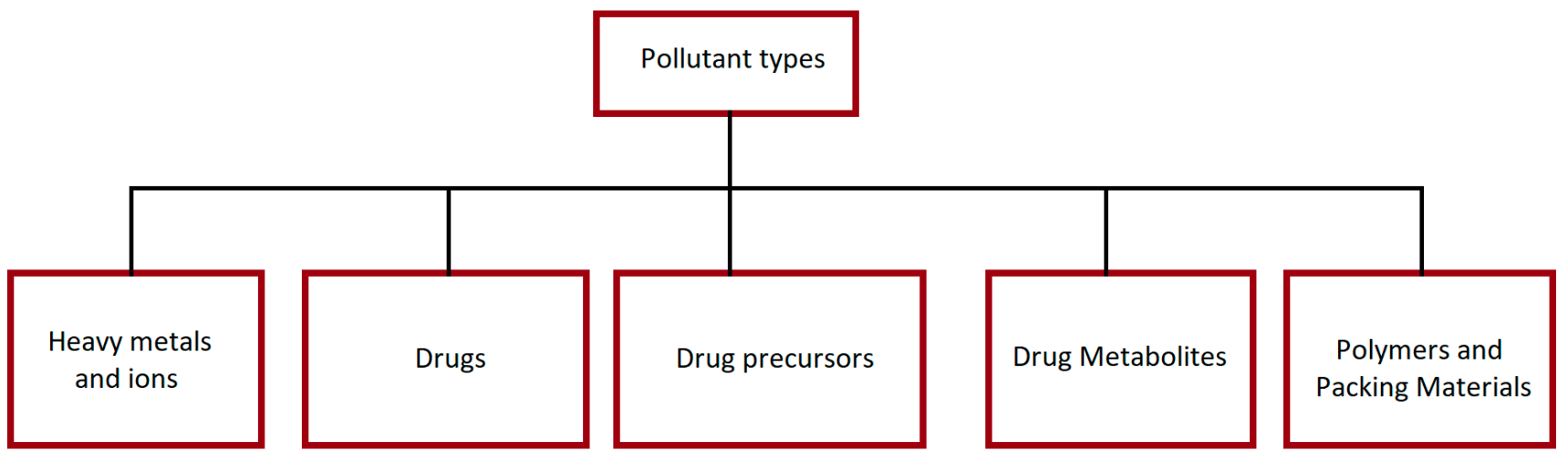

Figure 1. Classification of possible pollutants in PWW.

Various physicochemical parameters such as $\mathrm{pH}$, BOD, COD, and TSS, among others are all affected by these pollutants. Characterization of different pharmaceutical wastewater is shown in Table 2.

Table 2. Range of parameters in different PWW.

\begin{tabular}{|c|c|c|c|c|c|c|c|}
\hline \multirow{2}{*}{ Parameter } & \multicolumn{7}{|c|}{ References } \\
\hline & [45] & [46] & [47] & [48] & [49] & [50] & [51] \\
\hline $\mathrm{BOD}(\mathrm{mg} / \mathrm{L})$ & 120 & 304 & 900 & 22,000 & 200 & - & $263-330$ \\
\hline $\mathrm{COD}(\mathrm{mg} / \mathrm{L})$ & 490 & 420 & 4000 & 34,400 & 1753 & - & $2565-28,640$ \\
\hline $\mathrm{pH}$ & 6.9 & 7 & 5.2 & 7.2 & 7.3 & $5.65-6.89$ & $5.8-6.9$ \\
\hline TSS (mg/L) & 370 & 57 & 68 & 6250 & - & $29.67-123.03$ & $761-1202$ \\
\hline TDS (mg/L) & 1550 & - & - & - & - & 136.33-193.05 & $1443-3788$ \\
\hline TS (mg/L) & 1920 & 484 & - & 29,150 & - & - & - \\
\hline $\begin{array}{c}\text { Ammonium nitrogen } \\
(\mathrm{mg} / \mathrm{L})\end{array}$ & - & 52 & - & - & 220 & - & - \\
\hline $\mathrm{TP}(\mathrm{mg} / \mathrm{L})$ & - & 7.5 & 1.7 & - & 17 & - & - \\
\hline Chloride (mg/L) & - & 132 & - & - & 4.2 & - & - \\
\hline Turbidity (NTU) & - & - & 18 & - & - & $17.22-28.78$ & - \\
\hline Conductivity $\left(\mathrm{mS} \mathrm{cm}^{-1}\right)$ & - & - & 0.5 & - & 20 & $157-119.36$ & - \\
\hline Temperature $\left({ }^{\circ} \mathrm{C}\right)$ & - & 22 & 25 & $29-36$ & - & $32-46$ & $31-34$ \\
\hline
\end{tabular}

\section{Different Removal Technologies for Pharmaceutical Contaminants}

Various chemical, physical, and biological methods can be used for the extermination of pharmaceutical contaminants from PWW. The presence of a high COD amount [52], dissolved organic nitrogen [53], and salinity [54] make PWW more toxic and usually unfit for biological treatment. Therefore, a physio-chemical treatment is generally applied.

\subsection{Physiochemical Treatment Technologies}

Physicochemical processes are the most common treatment method for PWW. Usually, processes such as activated carbon adsorption, carbon nanotubes, electrocoagulation, and ozone treatment are used.

\subsubsection{Activated Carbon}

Briefly, activated carbon is a type of carbon that provides a larger surface area for adsorption by having low volume pores. Carbon can be powdered (PAC), granular (GAC), or bead-shaped (BAC). The removal capacity of pharmaceuticals by activated carbon depends on hydrophobicity, charges of pharmaceutical contaminants, and water matrix [55,56]. A variety of precursors is used to prepare AC out of biomass, such as cocoa shells [57], coffee residuals [58], palm leaflets [59], and fruit stones [60]. Sheng et al. (2016) reported an efficient pharmaceutical contaminants removal using integrated adsorption and filtration [61]. 


\subsubsection{Carbon Nanotubes}

Carbon nanotubes are hollow materials made up of single/multiple layer graphite sheets. It varies in terms of length and diameter according to the synthesis and requirement [62]. The presence of higher surface area and larger microspore volume makes it efficient for the removal of pharmaceuticals, heavy metals [63,64], dyes [65], phenol [66], and others. Shan et al. (2016) prepared novel granular carbon nanotubes by improving the surface area and pore volume and providing easy separation [67]. Apart from the numerous data available in this field, a knowledge gap still exists to understand better pharmaceuticals removal from PWW using nanotubes.

\subsubsection{Electrocoagulation}

In the electrocoagulation process, dissolved metal hydroxides remove the contaminants. The removal mechanism follows metal dissolution on anode and production of hydroxyl ion on the cathode [68]. This method is more economical and efficient than other physicochemical methods.

\subsubsection{Ozone Treatment}

Ozone treatment is considered an effective oxidant and disinfectant for a long time. It can oxidize many pharmaceuticals and organic matters present in wastewater and enhance biodegradability at natural $\mathrm{pH}$ [69]. Gome and Upadhyay (2013) applied ozone treatment on PWW under acidic or alkaline conditions. The authors reported that an ozone dose of $32.7 \mathrm{mg} / \mathrm{L}$ for acidic and $30.0 \mathrm{mg} / \mathrm{L}$ for alkaline was required [45].

\subsubsection{Advanced Oxidation Technologies}

Advanced oxidation technologies (AOTs) are being used to treat drinking water for a long time. Nowadays, it is also used for industrial effluents and PWW. AOTs include the Fenton process [70], $\mathrm{UV} / \mathrm{H}_{2} \mathrm{O}_{2}$ process [71], sonolysis [72], electrochemical oxidation [73], radiation [74], and combined advance oxidation technologies [75]. Since these technologies are based on the production of highly reactive oxygen species generated during this process, they are often used to treat pharmaceutical contaminants. In addition, the final products of AOTs are lesser harmful such as $\mathrm{CO}_{2}$, water, and acids [76].

\subsection{Bioremediation}

In general, bioremediation is applied to treat wastewater rich in carbon and nitrogen. Nevertheless, bioremediation is usually not sufficient in pharmaceutical contaminants, since PWW has high COD and many toxic substances. Bioremediation depends on several factors and operating conditions, e.g., toxicity, pollutant concentration, microbial strains' efficiency, climatic condition, and retention time [77]. Several studies have been performed on the removal of pharmaceuticals by different bioremediation technologies, e.g., bacterial bioremediation [78], active sludge process [79], membrane bioreactors [80], sequence batch reactor [81], and fungal bioremediation [82].

These methods have certain limitations, i.e., they require higher specificity [83], while some drugs show no removal [84].

\subsection{Membrane Technology}

Membrane-based treatment is a pressure-driven process that has become popular due to its energy efficiency and environmentally friendly nature [85]. The effectiveness of this method depends upon membrane fouling, selectivity, flux, and hydrophilicity [86]. Previously a myriad amount of work has been done for pharmaceuticals, including analgetics [87,88], antibiotics [89-91], and antidepressants [92] based on different membrane technology. Still, the limitations associated with the membrane fouling and high cost exist, thus preventing the wide industrial application. 


\section{Applicability of Electrocoagulation in Removal of Pharmaceuticals}

\subsection{Theory and Mechanism of EC}

EC technology is an old approach $[93,94]$. However, its application for the separation of contaminants is new $[95,96]$. Lately, it was found that electro-generated flocs are helpful in water decolorization [97]. Nowadays, this method is used to efficiently treat various wastewaters, including industrial, agricultural, and pharmaceuticals [98]. In a broad sense, EC is based on various mechanisms including physical (sorption, coagulation/flocculation), chemical (redox reaction, hydroxide precipitation), and electro-chemical (metal disintegration, water reduction, pollutant electro-oxidation/reduction) $[95,99]$, which are summarized in Figure 2.

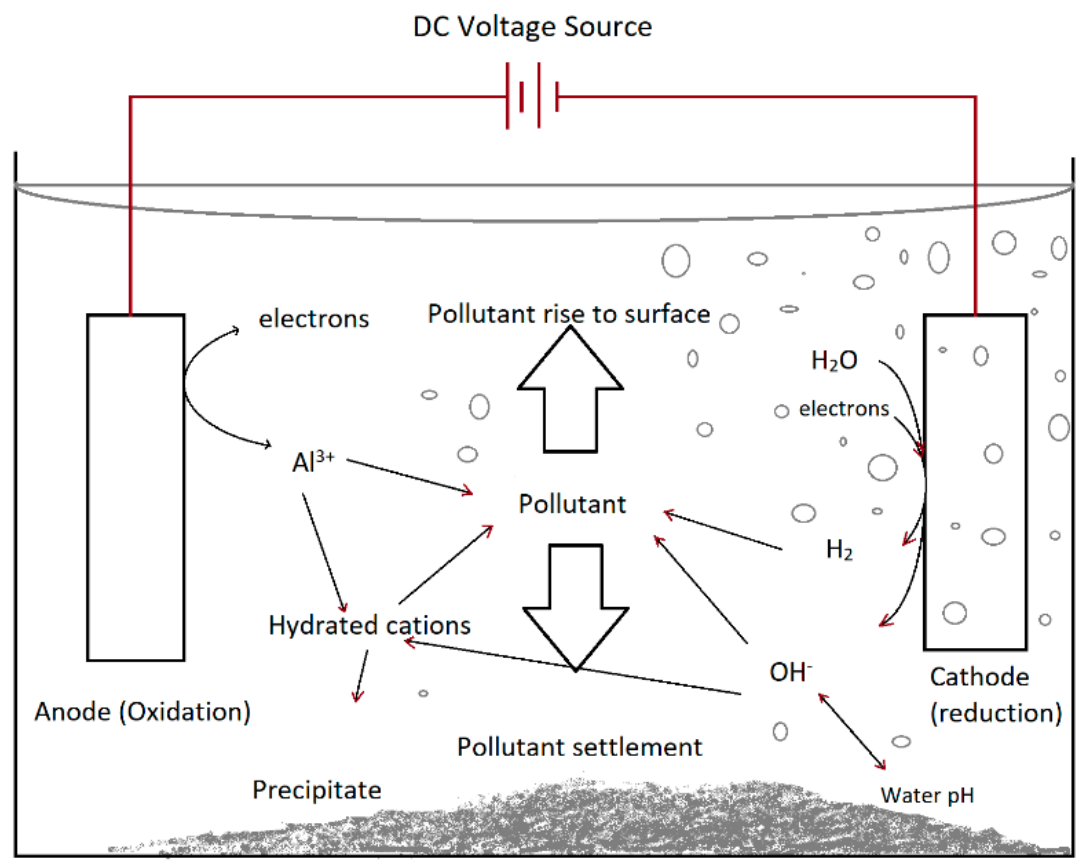

Figure 2. Interactions occurring within the EC reactor.

In this process, electric current $(\mathrm{DC} / \mathrm{AC})$ is used as the main power source. Utilizing the current and the appropriate electrodes, the contaminants become coagulated and separated by precipitation producing clean water. Generally, $\mathrm{Al} / \mathrm{Fe}$ electrodes are taken as sacrificial electrodes, and their disintegration occurs into the electrolyte. Coagulant species further react with dissolve/suspended pollutants, resulting in flocs production that can be easily isolated from the water $[100,101]$.

\subsection{EC Mechanisms}

The primary mechanism behind the EC process is the generation of in situ coagulant species by electro-dissolution of sacrificial electrodes usually aluminium or iron.

A general chemical equation would be as follows:

Metal is oxidized, and cations are formed at the anode according to Equation (1)

$$
\mathrm{M} \rightarrow \mathrm{M}^{\mathrm{Z}+}+\mathrm{Ze}^{-}
$$

where $\mathrm{Z}$ is the number of electrons transferred in this process; there are also chances of secondary reactions in case of the high potential anode.

At cathode: water is reduced, resulting in the production of hydroxyl ions and hydrogen gas.

$$
3 \mathrm{H}_{2} \mathrm{O}+3 \mathrm{e}^{-} \rightarrow \frac{3}{2} \mathrm{H}_{2}+3 \mathrm{OH}^{-}
$$


The amount of dissolved metal is solved with the help of Faraday's law [102,103].

$$
\mathrm{m}=\phi \frac{I t}{Z F} \mathrm{M}
$$

In Equation (3), $\mathrm{M}$ represents the atomic weight electrode of metal and $\mathrm{F}$ represents Faraday's constant [99]. Sometimes, a parallel reaction occurs, and all electrons do not participate in metal dissolution at the electrode. In this case, a correction factor, $\phi$ is required to compensate the difference between theoretical and experimental disintegration of the metallic anode [104,105]. Generally, the value of $\phi$ is less than 1 . However, when chemical and electrochemical oxidation happens on anode simultaneously, the value of $\phi$ exceeds 1 [106-108]. The released metal cation in the system undergoes several equilibrium reactions such as precipitation, acid/base, and redox reaction. However, the formation of metal hydroxides is the most common phenomenon that exhibits poor solubility and separates easily. Some of the metal hydroxides reactions with soluble pollutants are listed in Table 3.

Table 3. Extraction mechanism of distinct soluble pollutant via metal hydroxides.

\begin{tabular}{ccc}
\hline Soluble Pollutants in WW & Mechanism of Removal & References \\
\hline Organic Compounds & Complexation, co-precipitation & {$[109]$} \\
Phosphate Anions & Precipitation, Adsorption, Complexation & {$[110]$} \\
Sulphide Anions & Precipitation & {$[111]$} \\
Calcium Cations & Co-precipitation & {$[112]$} \\
Fluoride Anions & Complexation, Precipitation & {$[113]$} \\
\hline
\end{tabular}

The main mechanisms of pollutants removal through hydroxide precipitations are adsorption and complexation [114]. For some pollutants, the direct adsorption of pollutants on electrode occurs where pollutants are attracted toward anode due to electric forces [115]. A summary of these mechanisms is shown in Figure 3.

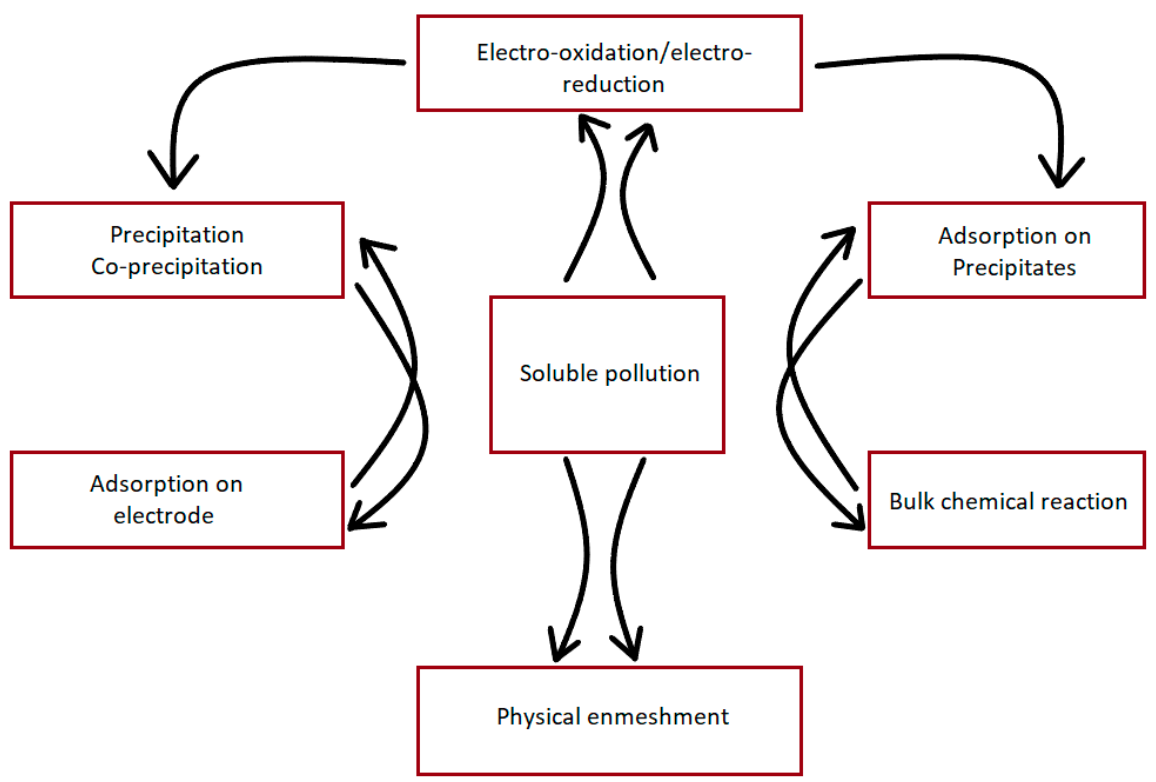

Figure 3. The main mechanism of soluble pollutant abatement using EC [99]. 


\subsection{EC Using Al Electrodes}

While using $\mathrm{Al}$ electrodes, $\mathrm{Al}^{3+} / \mathrm{Al}$ follows Equation (1), where $\mathrm{Z}=3$. Here, apart from the formation of metal hydroxides, other monomeric species are also formed, which follow acid/base reactions (Equations (4) and (7)).

$$
\begin{gathered}
\mathrm{Al}^{3+}+\mathrm{H}_{2} \mathrm{O} \rightarrow \mathrm{Al}(\mathrm{OH})^{2+}+\mathrm{H}^{+} \\
\mathrm{Al}(\mathrm{OH})^{2+}+\mathrm{H}_{2} \mathrm{O} \rightarrow \mathrm{Al}(\mathrm{OH})_{2}{ }^{+}+\mathrm{H}^{+} \\
\mathrm{Al}(\mathrm{OH})_{2}{ }^{+}+\mathrm{H}_{2} \mathrm{O} \rightarrow \mathrm{Al}(\mathrm{OH})_{3}+\mathrm{H}^{+} \\
\mathrm{Al}(\mathrm{OH})_{3}+\mathrm{H}_{2} \mathrm{O} \rightarrow \mathrm{Al}(\mathrm{OH})_{4}{ }^{-}+\mathrm{H}^{+}
\end{gathered}
$$

The role of $\mathrm{pH}$ prevails in aluminium speciation. $\mathrm{Al}(\mathrm{OH})_{3}$ predominates between $\mathrm{pH}$ 4-10. Otherwise, $\mathrm{pH}$ above 10 , soluble aluminate anions prevail, and $\mathrm{pH}$ below 4 , soluble $\mathrm{Al}^{3+}$ cations prevail.

\subsection{EC Using Fe Electrodes}

Electrochemical reactions become more complex using iron electrodes than aluminium as $\mathrm{Fe}^{2+} / \mathrm{Fe}^{3+}$ cations form after the anodic reaction.

$$
\begin{aligned}
& \mathrm{Fe} \rightarrow \mathrm{Fe}^{2+}+2 \mathrm{e}^{-} \\
& \mathrm{Fe} \rightarrow \mathrm{Fe}^{3+}+3 \mathrm{e}^{-}
\end{aligned}
$$

However, $\mathrm{Fe}^{2+}$ dissolution mainly prevails, as $\mathrm{Fe}^{3+}$ dissolution is negligible [116-118]. These ions become hydrolysed and form several monomeric/polymeric species depending on $\mathrm{pH}$ and $\mathrm{Fe}^{3+}$ concentration. Further, acid/base equilibrium reactions make it more complex. Anodic oxidation strongly depends on $\mathrm{O}_{2}$ concentration and $\mathrm{pH}[117,119]$. In alkaline/neutral media, $\mathrm{Fe}^{2+}$ species directly turn to ferrous hydroxide and further oxidizes into ferric hydroxide Equations (11) and (12). While at low $\mathrm{pH}$, they slowly react with oxygen and turn into $\mathrm{Fe}^{3+}(10)$.

$$
\begin{gathered}
\mathrm{Fe}^{2+}+\mathrm{O}_{2}+2 \mathrm{H}_{2} \mathrm{O} \rightarrow \mathrm{Fe}^{3+}+4 \mathrm{OH}^{-} \\
\mathrm{Fe}^{2+}+2 \mathrm{OH}^{-} \rightarrow \mathrm{Fe}(\mathrm{OH})_{2} \\
4 \mathrm{Fe}(\mathrm{OH})_{2}+\mathrm{O}_{2}+2 \mathrm{H}_{2} \mathrm{O} \rightarrow 4 \mathrm{Fe}(\mathrm{OH})_{3}
\end{gathered}
$$

Similar to Al dissolution, Fe dissolution on anode also follows Faraday's law where the value of $\phi$ is around 0.8-1.0 [106-108]. Despite this, the value is greater than one at lower $\mathrm{pH}$ [116]. Finally, several monomeric/polymeric species become amorphous precipitate $\left(\mathrm{Fe}(\mathrm{OH})_{3}\right)$ that assist adsorption of soluble and trapping of insoluble contaminants $[120,121]$.

\section{Parameters Affecting EC}

\subsection{Initial $p H$}

One of the most significant factors influencing the EC process is the initial $\mathrm{pH}$. It mainly depends on the type of contaminants, anode material, and reaction mechanisms. However, it increases as the reaction proceeds [122]. Thus, a reaction mechanism is needed to optimize $\mathrm{pH}$ for effective removal [123]. Pharmaceutical plants produce effluents with a broad $\mathrm{pH}$ range, from very acidic to alkaline. Lots of studies show that $\mathrm{pH}$ has a significant impact on the EC process and treatment effectiveness. The type of EC-causing species and the solubility all depend on $\mathrm{pH}[124,125]$.

Apart from a general process, $\mathrm{pH}$ also has a vital role for specific pharmaceuticals such as tetracycline-related compounds. For acidic $\mathrm{pH}$ (less than 3.3), tetracycline is a cation due to the presence of protonated dimethyl ammonium group. At medium $\mathrm{pH}$ (3.3-7.7), the phenolic diketone moiety loses a proton and forms zwitterion. Lastly, at high $\mathrm{pH}$ (greater than 7.7), tetracycline is present as a monovalent/divalent anion [126]. 


\subsection{Duration of Electrocoagulation Treatment}

The duration of EC treatment is another critical factor that directly affects the EC process. Regardless of the current density used, removal efficiencies are directly proportional to the time of electrolysis [127]. Increased electrolysis time leads to the increment of generation of complex aluminium ions, hydrogen bubbles through electrodissolution of the anode, and reduction in the cathode. However, the removal efficiency only increases with time until an optimal value. The removal efficiency becomes constant outside the optimum time limit due to excess coagulant [128]. Although a slight increment in the duration could increase the removal efficiency in light of the price and process suitability, the optimum duration for the EC is usually considered 20-30 $\min [118,129]$.

\subsection{Current Density (CD)}

$\mathrm{CD}$ has a significant impact on the EC process, since it controls the rate at which coagulant is added, the evolution of gas, the formation of bubbles, the size of the floc, and the EC operating costs resulting in faster pollutant removal $[130,131]$. BOD, COD, and colour removal increase with the current density, and hence, the treatment time decreases. Increased current causes faster anode disintegration, results in increased precipitation, and more bubble production, which accounts for more flocculation and coagulation, resulting in higher removal [132]. The number of flocs produced is a function of the amount of treatment time and the $C D$ used. High CD increases the quantity and rate of floc generation that collects a lot of suspended solids and increases the amount of sludge generated. In addition, excess metal hydroxide flocs are hard to float, resulting in operational shortfalls [133]. In addition, using high CD, much of the energy is lost in the water electrolysis reaction and heating due to the joule effect. Therefore, it is crucial to operating the device at an optimum CD [21]. For removing oxytetracycline hydrochloride, Nariyan et al. (2017) reported that the optimum current density was $20 \mathrm{~mA} \cdot \mathrm{cm}^{-2}$ using Fe/ Al [134].

\subsection{Mode of Electricity Application}

The constant supply of electricity ensures the continuous supply of $\mathrm{Al}^{3+}$ species, which are responsible for the charge neutralization and eventual precipitation of suspended micropollutants and simultaneous adsorption of dissolved organic matter and other chemical species. However, intermittent electricity supply can reduce the consumption of energy and electrode material, since the metal dissolution stops between the gaps [135]. As a consequence, intermittent electrical supply limits anode passivation. The energy consumption is calculated by Equation (13).

$$
\mathrm{Q}=\text { V.I.t. } \theta^{2}
$$

where $\mathrm{Q}$ denotes consumption (Wh); $\mathrm{V}$ denotes peak voltage (V); I denotes peak current (A); $t$ denotes reaction time (s); $\theta$ denotes intermittent cycle, which is 1 in case of continuous current supply.

Ensano et al. (2017) studied the extraction of pharmaceutical waste by intermittent coagulation (5 min ON/20 min OFF) and reported 90\% removal of diclofenac at a current density of $0.5 \mathrm{~mA} / \mathrm{cm}^{2}$ for HRT of $38 \mathrm{~h}$ [24].

\subsection{Electrode Material}

The electrocoagulation process revolves around the vital role of electrodes. Consequently, parameters and configurations, including electrode materials, spacing, shape, and arrangement, are highly significant. Several materials such as $\mathrm{Al}, \mathrm{Fe}, \mathrm{Zn}, \mathrm{Ag}, \mathrm{Na}, \mathrm{Mg}, \mathrm{Si}$, $\mathrm{Ca}, \mathrm{Sr}$, and $\mathrm{Cd}$ are used as electrodes in EC [136]. In addition, using graphite and lead oxide as electrode materials for EC is also reported [137]. These materials are different in terms of their chemical and physical properties. $\mathrm{Al}$ and Fe electrodes are the most frequently used materials for the electrode in electrocoagulation applications because they are inexpensive, non-toxic, readily available, and proven reliable. Researchers applied electrocoagulation to treat olive mill wastewater with both iron and sacrificial aluminium electrodes [138]. They observed that the aluminium electrode was more efficient at reducing COD in wastewater. 


\subsection{Electrode Spacing}

Electrode spacing is directly linked to the functioning of the EC, as it can alter electrostatic attraction, the in-between residence time, turbulence, mass transfer, and finally, pollutant removal efficiency. For instance, the electrostatic force between metal hydroxide flocs would be very high at low spacing; therefore, degradation of flocs will occur due to intensive collision [139]. On the other hand, at higher electrode spacing, the time for agglomeration of produced metal hydroxide is enough with fewer flocs degradation, and hence, the removal efficiency increased. However, if the spacing increased beyond the optimum range, the removal efficiency decreased due to the decreased flocs formation and increased potential drop [140].

\subsection{Electrode Arrangement}

Irrespective of the ease of the general EC set-up, they are not widely applicable for industrial wastewater treatment, as they require a large surface area of the electrode. However, this drawback can be solved by using series/parallel monopolar or bipolar systems of electrodes. In a complex EC system, three different electrode arrangements are reported [141,142].

1. Monopolar parallel electrodes (MP-P): In the MP-P setup, both oppositely charged electrodes are joined to one another and farther to the outer circuit. As the currents divide in this arrangement, the potential difference becomes lower [143] (Figure 4a).

2. Monopolar-series electrodes (MP-S): In the MP-S setup, each internal pair of sacrificial electrodes are joined to one another making an equal amount of current supply in each. However, the voltage is additive here (Figure $4 b$ ).

3. Bipolar series electrodes (BP-S): In the BP-S arrangement, two of the outer monopolar electrodes are joined to the external circuit, and internal bipolar sacrificial electrodes are without a connection. Here, on the positive side, oxidation of meal takes place, and the cathodic reaction takes place on the negative side [144] (Figure 4c).

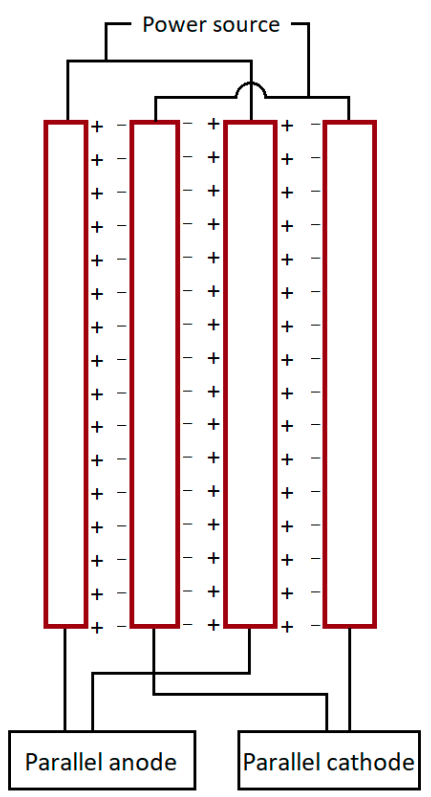

(a)

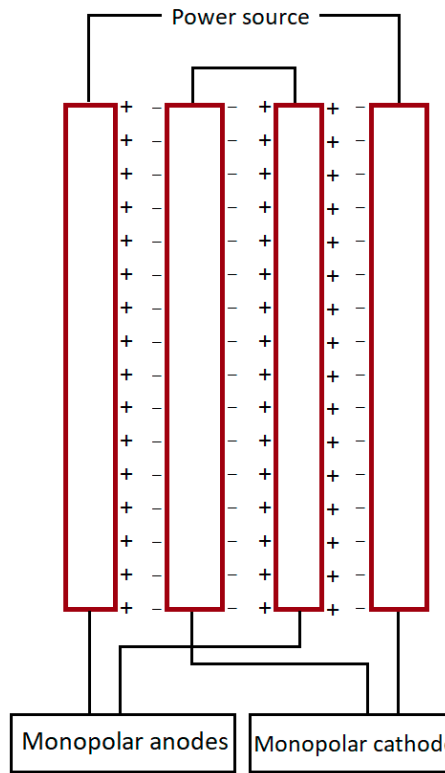

(b)

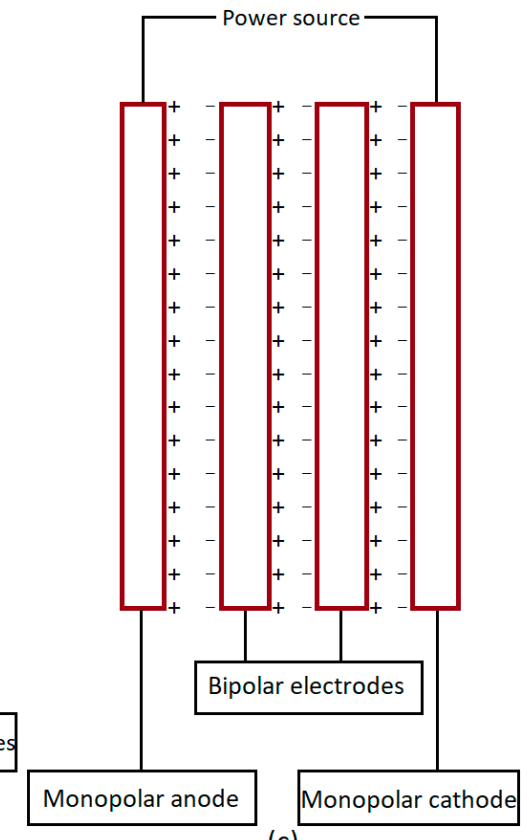

(c)

Figure 4. Different electrodes arrangements in an electrochemical cell: (a) MP-P; (b) MP-S; (c) BP-S. 


\subsection{Electrode Shape}

Electrodes have been used in several shapes such as rectangular, circular, cylindrical, punched hole type in which rectangular shape is the most common. Generally, they are placed vertically. However, in some studies, horizontal placement of electrodes is also reported, which enhanced the mixing efficiency $[145,146]$. Another study based on a comparison of punched vs. plane electrodes claimed that punched electrodes have higher collection efficiency and higher electric field on the punched edges [147].

\subsection{Mode of Power Supply}

Supplies in the form of DC power are generally used for electro-coagulation cells. Several studies have been carried out using DC sources except for a very few studies where the AC source had been implemented $[128,136]$. However, the use of DC means that the anode is oxidized, and a layer of oxide is developed on the cathode called as cathode passivation. This passive layer results in the decrease in the current flow between both electrodes, and the efficiency of EC decreases. Passivity results in overpotential, which leads to a large amount of energy utilization. Several study results with supply in the form of AC were promising. Mollah et al. (2004) noticed that AC supply ensures an adequate life of electrodes by cyclic energy that hinders DC's conventional consumption [142]. The AC and DC supply reaction on cadmium removal from water through electrical coagulation has been examined by Vasudevan et al. (2011) [134]. The results have shown that less energy and greater removal efficiency were achieved using an AC power supply.

Ahmadzadeh et al. (2017) studied optimal conditions for the elimination of ciprofloxacin from hospital wastewater with the help of response surface methodology. The optimal conditions were $\mathrm{pH} 7.78$, electrode spacing $1 \mathrm{~cm}, \mathrm{CD} 12.5 \mathrm{~mA} / \mathrm{cm}^{2}$, reaction time $20 \mathrm{~min}$, initial concentration of ciprofloxacin $32.5 \mathrm{mg} / \mathrm{L}$, and $0.07 \mathrm{M} \mathrm{NaCl}$ as the electrolyte [148]. Some of the previous studies based on pharmaceutical removal by EC are summarized in Table 4 below.

Table 4. Few past studies carried out for pharmaceutical removal by EC.

\begin{tabular}{|c|c|c|c|c|}
\hline Source of Wastewater & Pharmaceutical Contaminants & Experimental Conditions & $\%$ Removal Efficiency & References \\
\hline Pharmaceutical Wastewater & $\begin{array}{l}\text { Oxytetracycline } \\
\text { Hydrochloride }\end{array}$ & $\begin{array}{l}\text { Iron/aluminium anode }(70 \times 50 \mathrm{~mm}) \text {; } \\
\text { Stainless steel cathode }(70 \times 50 \mathrm{~mm}) ; \\
\text { The gap between electrodes: } 5 \mathrm{~cm} ; \\
20 \mathrm{mAcm}^{2} \text { current density; } \\
\text { Time to react: } 120 \text { min; } \\
0.19 \mathrm{kWh} / \mathrm{L} \text { power consumption; } \\
200-50 \mathrm{mg} / \mathrm{L} \text { as a starting } \\
\text { concentration. }\end{array}$ & $82.96-93.17$ & [134] \\
\hline Hospital Wastewater & Ciprofloxacin (CIP) & $\begin{array}{l}\text { Aluminium anode and cathode; } \\
\text { pH- } 7.78 ; \\
\text { Inter-electrode distance: } 1 \mathrm{~cm} ; \\
\text { Time to react: } 20 \text { min; } \\
12.5 \mathrm{mAcm} 2 \text { current density; } \\
32.5 \mathrm{mg} / \mathrm{L} 1 \text { as a starting point. }\end{array}$ & 88.57 & [148] \\
\hline Pharmaceutical Wastewater & COD & $\begin{array}{c}\text { Aluminium anode and cathode ( } 150 \\
\mathrm{~cm}^{2} \text { ); } \\
\text { Distance between electrodes: } 25 \mathrm{~mm} \text {; } \\
\text { pH: } 3-9 ; \\
1.7-1.9 \mathrm{mAcm}^{2} \text { current density; } \\
\text { The electrical voltage is } 40 \text { volts. } \\
\text { 60-min response time. }\end{array}$ & 34.2 & [21] \\
\hline \multirow[t]{3}{*}{ Water Containing Heavy Metals } & Arsenic & $\begin{array}{l}\text { Aluminium (both the anode and the } \\
\text { cathode); } \\
\text { Bipolar electrode configuration. }\end{array}$ & 93 & [149] \\
\hline & Chromium (VI)- Pb & $\begin{array}{c}\text { Electrodes SS-SS; } \\
\text { Current density }\left(\mathrm{A} / \mathrm{m}_{2}\right) \text { 73.5; } \mathrm{pH} 3.5 ; \\
\text { Content: } 55.3-3.5[\mathrm{mg} / \mathrm{L}] ; \\
\text { Electrodes SS-SS; } \\
\text { Current density }\left(\mathrm{A} / \mathrm{m}^{2}\right) \text { 73.5; } \mathrm{pH} 3.5 ;\end{array}$ & $91.7-91.3$ & [150] \\
\hline & $\begin{array}{c}\text { Perfluorobutane } \\
\text { sulfonate (PFBS) } \\
\text { Perfluorohexane sulfonate } \\
\text { (PFHxS) } \\
\text { Perfluorooctane sulfonate (PFOS) } \\
\text { Perfluoroalkane sulfonic acids } \\
\text { (PFSAs) }\end{array}$ & $\begin{array}{l}\text { Electrode: Al-Zn } \\
\text { Voltage supply: } 12 \mathrm{v} \\
\text { pH: } 7\end{array}$ & $\begin{array}{l}87.4 \\
95.6 \\
100 \\
100\end{array}$ & [151] \\
\hline
\end{tabular}

\section{Combined Electrocoagulation Processes}

Several combined EC processes have been applied to increase pollutant removal efficiency and compensate for the cost. In these processes, EC can be applied with an- 
other treatment method as a pre/post-treatment unit depending on the type of pollutants present [47-49,152]. In addition, an overview of selected studies on different PWW treatment using EC/combined EC with pollutant removal efficiency at optimum condition is summarized in Table 5.

\subsection{Combined EC/adsorption (CEA) Process}

CEA is a relatively new technique and efficient in terms of cost and performance [153]. The authors analysed the removal efficiency by applying the EC treatment process followed by bioadsorption using $\mathrm{Al}$ as an electrode and Ectodemis of Opuntia as bioadsorbent. It reports that removal of COD was $50 \%$ by EC and a further $60 \%$ by bioadsorption. The colour removal was also higher in the combined EC/bioadsorption process. Recently, several works have been published on combined EC/adsorption, mainly on industrial wastewater. Aouni et al. reported removing COD, colour, and turbidity by $98.33 \%, 98.37 \%$, and $100 \%$, respectively, using a combined EC/adsorption process from textile wastewater [154].

\subsection{Combined Chemical Coagulation (ECCC)/EC Process}

Several studies were done on the removal of pollutants by combining EC/chemical coagulation with the help of suitable coagulants before EC to enhance performance and reduce the cost $[155,156]$. Can et al. (2006) studied the impact of two different coagulants before EC for removing COD and achieved a maximum removal of $80 \%$ [157]. Recently, Muharam et al. (2017) investigated the performance of EC, CC, and combined ECCC on medical wastewater. Authors reported removing total organic compound (TOC) using CC, combined ECCC, and EC processes by $41 \%, 92.21 \%$, and $62.51 \%$, respectively [158]. These results indicate that the combined $\mathrm{EC} /$ chemical coagulation enhances different pollutants $^{\prime}$ removal efficiency, including pharmaceuticals from wastewater.

Table 5. Summary of EC applied for wide range of PWW with pollutant removal efficiency at optimum condition.

\begin{tabular}{|c|c|c|c|c|c|c|c|c|c|c|}
\hline $\begin{array}{c}\text { Type of } \\
\text { Wastewater }\end{array}$ & $\begin{array}{c}\text { Electrode } \\
\text { Material(Anode- } \\
\text { Cathode) }\end{array}$ & $\begin{array}{l}\text { Optimal } \\
\text { Current } \\
\text { Density }\end{array}$ & $\begin{array}{c}\text { Mode of } \\
\text { Electricity Ap- } \\
\text { plication/Type }\end{array}$ & $\begin{array}{c}\text { Electrode } \\
\text { Arrangement }\end{array}$ & $\begin{array}{l}\text { Electrodes } \\
\text { Spacing }\end{array}$ & $\begin{array}{c}\text { Initial } \\
\text { Concentration }\end{array}$ & $\begin{array}{l}\text { Initial } \mathrm{pH} \text { and } \\
\text { Temperature }\end{array}$ & $\begin{array}{c}\text { Treatment } \\
\text { Time }\end{array}$ & Pollutant Removal & Source \\
\hline Synthetic PWW & $\mathrm{Al}-\mathrm{Fe}$ & $0.5 \mathrm{~mA} / \mathrm{cm}^{2}$ & $\begin{array}{l}\text { Intermittent (5 } \\
\min \text { ON/20 } \\
\text { min OFF) }\end{array}$ & - & $5 \mathrm{~cm}$ & $10 \mathrm{mg} / \mathrm{L}$ & $\begin{array}{l}\mathrm{pH}=7.5, \\
\mathrm{~T}=25^{\circ} \mathrm{C}\end{array}$ & $38 \mathrm{~h}$ & $\begin{array}{c}\text { Diclofenac }=90 \% \\
\text { carbamazepine }(\text { CBZ })= \\
70 \% \text {, Amoxicillin }(\text { AMX) } \\
=77 \%\end{array}$ & [24] \\
\hline $\begin{array}{l}\text { Pharmaceutical } \\
\text { industry } \\
\text { wastewater }\end{array}$ & $\mathrm{Fe}-\mathrm{Fe}$ & $15 \mathrm{~mA} / \mathrm{cm}^{2}$ & $\begin{array}{l}\text { Combined EC } \\
\text { (EC/electro- } \\
\text { Fenton) }\end{array}$ & MP-P & $2 \mathrm{~cm}$ & $\begin{array}{c}\mathrm{COD}=4000 \\
\mathrm{mg} / \mathrm{L} \\
\mathrm{TOC}=1200 \\
\mathrm{mg} / \mathrm{L} \\
\mathrm{BOD}=900 \\
\mathrm{mg} / \mathrm{L}\end{array}$ & $\begin{array}{c}\mathrm{pH}=7 \\
\mathrm{~T}=25^{\circ} \mathrm{C}\end{array}$ & $2 \mathrm{~h}$ & $\begin{array}{c}\mathrm{COD}=70.2 \% \\
\mathrm{TOC}=64 \% \\
\mathrm{BOD}=97 \%\end{array}$ & [47] \\
\hline $\begin{array}{l}\text { Pharmaceutical } \\
\text { effluents }\end{array}$ & $\mathrm{Al}-\mathrm{Al}$ & $46.83 \mathrm{~mA} / \mathrm{cm}^{2}$ & $\begin{array}{l}\text { Continuous } \\
\text { electricity } \\
\text { application }\end{array}$ & - & $1 \mathrm{~cm}$ & $\begin{array}{c}\text { Conductivity = } \\
784 \mu \mathrm{S} / \mathrm{cm}, \\
\text { turbidity }=784 \\
\text { NTU, } \\
\text { COD }=525 \\
\mathrm{mg} / \mathrm{L}\end{array}$ & $\mathrm{pH}=5.31$, & $18 \mathrm{~min}$ & $\begin{array}{c}\text { Turbidity }=96.7 \% \\
\text { COD }=70.8 \%\end{array}$ & [159] \\
\hline $\begin{array}{l}\text { Synthetic PWW } \\
\text { (Oxytetracy- } \\
\text { cline } \\
\text { hydrochloride) }\end{array}$ & $\begin{array}{l}\mathrm{Al}-\mathrm{Al} \\
\mathrm{Fe}-\mathrm{Fe}\end{array}$ & $20 \mathrm{~mA} / \mathrm{cm}^{2}$ & $\begin{array}{l}\text { Continuous } \\
\text { electricity } \\
\text { application }\end{array}$ & MP-P & $5 \mathrm{~cm}$ & $50 \mathrm{mg} / \mathrm{L}$ & - & $120 \mathrm{~min}$ & $\begin{array}{l}87.75 \% \\
93.20 \%\end{array}$ & [134] \\
\hline Drug industry & $\mathrm{Al}-\mathrm{Al}$ & $80 \mathrm{~A} / \mathrm{m}^{2}$ & $\begin{array}{c}\text { Combined EC } \\
\text { (EC/anaerobic } \\
\text { process) }\end{array}$ & - & $1 \mathrm{~cm}$ & $\begin{array}{c}\mathrm{COD}=34,400 \\
\mathrm{mg} / \mathrm{L} \\
\mathrm{BOD}=22,000 \\
\mathrm{mg} / \mathrm{L}\end{array}$ & $\mathrm{pH}=7.2$ & $25 \mathrm{~min}$ & $\begin{array}{c}\mathrm{COD}=24 \% \\
\mathrm{BOD}=35 \% \\
\text { Colour }=70.25 \%\end{array}$ & [48] \\
\hline $\begin{array}{l}\text { Pharmaceutical } \\
\text { factory } \\
\text { wastewater }\end{array}$ & $\mathrm{Fe}-\mathrm{Fe}$ & $763 \mathrm{~A} / \mathrm{m}^{2}$ & $\begin{array}{l}\text { Combined EC } \\
\text { (EC/photocatalysis) }\end{array}$ & MP-P & $2 \mathrm{~cm}$ & - & $\begin{array}{l}\mathrm{pH}=6.0, \\
\mathrm{~T}=25^{\circ} \mathrm{C}\end{array}$ & $90 \mathrm{~min}$ & $\begin{array}{c}\text { Turbidity }=91 \% \\
\text { COD }=86 \%\end{array}$ & [49] \\
\hline $\begin{array}{l}\text { Artificial PWW } \\
\text { (Amoxicillin) }\end{array}$ & $\mathrm{Al}-\mathrm{Al}$ & $0.7 \mathrm{~A}$ & $\begin{array}{l}\text { Combined EC } \\
\text { (EC/nanofiltration) }\end{array}$ & MP-P & $1 \mathrm{~cm}$ & $50 \mathrm{mg} / \mathrm{L}$ & $\begin{array}{l}\mathrm{pH}=2.5, \\
\mathrm{~T}=25^{\circ} \mathrm{C}\end{array}$ & $60 \mathrm{~min}$ & $52.7 \%$ & [160] \\
\hline $\begin{array}{l}\text { Pharmaceutical } \\
\text { effluent }\end{array}$ & Fe-Al & $0.04 \mathrm{~A}$ & $\begin{array}{l}\text { Continuous } \\
\text { electricity } \\
\text { application }\end{array}$ & - & $1 \mathrm{~cm}$ & $\begin{array}{c}\mathrm{COD}=7692 \\
\mathrm{mg} / \mathrm{L} \\
\mathrm{TDS}=16,290 \\
\mathrm{mg} / \mathrm{L} \\
\text { chloride = } \\
\mathrm{mg} / \mathrm{L}\end{array}$ & $\mathrm{T}=25-27^{\circ} \mathrm{C}$ & $15 \mathrm{~min}$ & $\begin{array}{l}\mathrm{COD}=92.3 \% \\
\mathrm{TDS}=91.5 \%\end{array}$ & [161] \\
\hline $\begin{array}{l}\text { Synthetic PWW } \\
\text { (Amoxicillin) }\end{array}$ & $\mathrm{Al}-\mathrm{Al}$ & - & $\begin{array}{l}\text { Continuous } \\
\text { electricity }\end{array}$ & BP-S & $2.5 \mathrm{~cm}$ & $10 \mathrm{mg} / \mathrm{L}$ & $\mathrm{pH}=7$ & $75 \mathrm{~min}$ & $98.8 \%$ & [162] \\
\hline $\begin{array}{c}\text { Berberine } \\
\text { hydrochloride } \\
\text { (BH) } \\
\text { wastewater }\end{array}$ & $\mathrm{Fe}-\mathrm{Fe}$ & $19.44 \mathrm{~mA} / \mathrm{cm}^{2}$ & Pulse EC & MP-P & $2 \mathrm{~cm}$ & $\begin{array}{c}\mathrm{BH}=1500 \\
\mathrm{mg} / \mathrm{L}\end{array}$ & $\mathrm{pH}=7$ & $3.5 \mathrm{~h}$ & $\mathrm{BH}=72.8 \%$ & [163] \\
\hline
\end{tabular}




\subsection{Combined Membrane/EC Process}

Regardless of the several types of EC combination, there are few studies on the combination of membrane separation with EC [164,165]. Hakizimana et al. (2017) studied pollutant removal in seawater using EC pretreatment in combined membrane/EC. The authors concluded that this method was cost effective, particularly for the seawater, due to high conductance [99]. Another study on the membrane-assisted EC process was investigated by Sardari et al. (2018). In this study, EC followed by direct contact membrane distillation (DCMD) was investigated. The authors concluded that the combined ECDCMD process was efficient for the removal of organic matter and suspended solids. Further, they reported that this method could maximize water recovery and minimize the concentration of brine [166].

\subsection{Combined Sono/Electrocoagulation Process}

It is a combined process of EC with ultrasound irradiation that promotes agitation resulting in homogeneity in the system. However, simultaneous ultrasonication sometimes produces undesirable effects such as destruction of the produced colloidal hydroxides and their adsorption layer by ultrasound waves, reducing the removal efficiency [167]. However, the combined process has several advantages: the production of free radicals intense mixing and the reduction in anodic passivation effect if a controlled frequency is applied $[168,169]$. Raschitor et al. (2014) reported $95 \%$ removal by combined sono-EC, while the removal was only $60 \%$ using EC alone [169].

\section{Cost Analysis}

Any wastewater treatment method must be cost effective. Therefore, techno-economic analysis plays a significant role in proposing a process of treatment. Limited work has been done on the cost analysis during electrocoagulation, particularly for contaminants removal from PWW. The utilization of electricity is an essential aspect in influencing the operational cost in the EC process. To be industrially scalable, this technique must be economically viable [170]. Thus, a low-cost EC technology is required to scale up on an industrial level [171]. Cell voltage, reaction time, and current can all be used to calculate electricity utilization in an EC operation. When electric current density exceeds the optimum amount, undesirable responses will arise, extra oxygen will expand, and cell energy will be increased, resulting in increased power utilization and operating costs [172]. Apart from the costs of electricity, the expenses of chemicals and sacrificial electrodes are the other main components used in calculating the cost of an electro-chemical device $[130,173,174]$. Thus, energy usage, complete dissolution of the electrode, any cost add up of chemical substances (adjustment of the conductivity or altering solution $\mathrm{pH}$ ), and cost of disposal and transportation of sludge are all part of the EC process costs. However, the use of a renewable energy source and process optimization could reduce the overall cost. Several studies have been conducted on the reduction in EC process cost. For instance, [175] reduced the overall EC cost for $\mathrm{Cr}(\mathrm{VI})$ treatment using multivariate optimization of a process variable. In another study, using response surface methodology (RSM), all process affecting variables optimized to make the treatment cost effective [176]. Some of the typical cost analysis on the EC process are included in this review. The operational expense of treating real dye house wastewater with continuous flow electrocoagulation was calculated by M Kobya et al. (2016) [133]. The cost of operation was shown as energy expenses, cost of electrode materials, and chemical utilization expenses. Expenses of utilizing electrode of aluminium were estimated as $1.851 \mathrm{USD} / \mathrm{m}^{3}$ in comparison to $1.562 \mathrm{USD} / \mathrm{m}^{3}$ using electrodes of iron at the optimum working conditions of $80 \mathrm{~min}$ of operation, current density of $65 \mathrm{~A} / \mathrm{m}^{2}$, and $0.010 \mathrm{~L} / \mathrm{min}$ of flow.

Espinoza et al. (2009) examined the efficacy of electro-coagulation in tannery wastewater treatment [177]. Electrocoagulation was more cost effective compared to other conventional methods and achieved the required removal. More specifically, the estimated expenses of electro-coagulation were 1.7 dollars per $\mathrm{m}^{3}$ of treated effluent versus 3.5 
dollars per $\mathrm{m}^{3}$ using the conventional process. Khaled et al. (2019) looked into the effects of different design parameters of reactors on the performance and operating costs of electro-coagulation to remove cadmium from wastewater [178]. Electrodes distance, electrode attachment mode, stirring speed, surface area to volume ratio (S/V), and initial temperature were all investigated. The expenses of electrodes (aluminium), electricity, and chemicals applied to alter $\mathrm{pH}$ were all considered in this study's operating costs. At specific conditions of $0.5 \mathrm{~cm}$ inter-electrode distance, 50 degrees Celsius initial temperature, stirring speed of 300 revolution/min, ratios of $\mathrm{S} / \mathrm{V}$ as 13.5 , and monopolar connection mode, 100 percent cadmium extraction was achieved with less power utilization and a minimum operating expenses of 0.116 TND (Tunisian National Dinar, equal to 0.06 USD). The authors also stated a cost of 4.36 TND (2.1 USD) for chemical coagulation, demonstrating that electro-coagulation is more cost effective. Some of the operating costs in different wastewater using EC are summarized in Table 6.

Table 6. Few EC based studies indicating operation cost in different condition.

\begin{tabular}{|c|c|c|c|c|c|c|}
\hline $\begin{array}{c}\text { Type of } \\
\text { Wastewater }\end{array}$ & Initial Conc. & $\begin{array}{l}\text { Electrode } \\
\text { Material }\end{array}$ & $\begin{array}{l}\text { Removal } \\
\text { Efficiency }\end{array}$ & $\begin{array}{l}\text { Current } \\
\text { Density }\end{array}$ & $\begin{array}{l}\text { Operating } \\
\text { Cost }\end{array}$ & Reference \\
\hline $\begin{array}{c}\text { Synthetic } \\
\text { Wastewater }\end{array}$ & $100 \mathrm{mg} / \mathrm{L}$ & $\mathrm{Al}$ & $80-95 \%$ & $\begin{array}{c}208-310 \\
\mathrm{~A} / \mathrm{m}^{2}\end{array}$ & $\begin{array}{l}0.34-0.52 \\
\text { USD/kg dye }\end{array}$ & [179] \\
\hline $\begin{array}{c}\text { Synthetic } \\
\text { Wastewater }\end{array}$ & $50 \mathrm{mg} / \mathrm{L}$ & $\begin{array}{l}\mathrm{Al} \\
\mathrm{Fe}\end{array}$ & $\begin{array}{l}87.5-93.4 \% \\
90.7-98.1 \%\end{array}$ & $\begin{array}{c}155-350 \\
\mathrm{~A} / \mathrm{m}^{2} \\
155-350 \\
\mathrm{~A} / \mathrm{m}^{2}\end{array}$ & $\begin{array}{c}7.04-17.4 \\
\text { USD / kg dye } \\
4.01-13.8 \\
\text { USD/kg dye }\end{array}$ & [180] \\
\hline $\begin{array}{l}\text { Coal Mine } \\
\text { Drainage }\end{array}$ & - & $\mathrm{Fe}$ & $28.7-99.96 \%$ & $\begin{array}{l}200-500 \% \\
\text { A/M2 }\end{array}$ & $\begin{array}{l}1.09-2.184 \\
\text { USD } / \mathrm{m}^{3}\end{array}$ & [181] \\
\hline $\begin{array}{l}\text { Textile Dye } \\
\text { Wastewater }\end{array}$ & $\begin{array}{l}3422 \mathrm{mg} / \mathrm{L} \\
\mathrm{COD}\end{array}$ & $\begin{array}{l}\mathrm{Al} \\
\mathrm{Fe}\end{array}$ & $\begin{array}{l}15-62 \% \\
57-78 \%\end{array}$ & $\begin{array}{l}50-200 \mathrm{~A} / \mathrm{m}^{2} \\
50-200 \mathrm{~A} / \mathrm{m}^{2}\end{array}$ & $\begin{array}{c}0.32-0.58 \\
\text { USD } / \mathrm{kg} \text { COD } \\
0.7-0.175 \\
\text { USD } / \mathrm{kg} \text { COD }\end{array}$ & [182] \\
\hline $\begin{array}{l}\text { Textile Dye } \\
\text { Wastewater }\end{array}$ & $\begin{array}{l}2031 \mathrm{mg} / \mathrm{L} \\
\mathrm{COD}\end{array}$ & $\begin{array}{l}\mathrm{Al}(\mathrm{MP}-\mathrm{P}) \\
\mathrm{Fe}(\mathrm{MP}-\mathrm{P})\end{array}$ & $\begin{array}{l}- \\
-\end{array}$ & $\begin{array}{l}30-60 \mathrm{~A} / \mathrm{m}^{2} \\
30-60 \mathrm{~A} / \mathrm{m}^{2}\end{array}$ & $\begin{array}{c}0.4-0.65 \\
\mathrm{USD} / \mathrm{m}^{3} \\
0.25-0.4 \\
\mathrm{USD} / \mathrm{m}^{3}\end{array}$ & [183] \\
\hline $\begin{array}{l}\text { Wastewater from } \\
\text { Metal Industries }\end{array}$ & $\begin{array}{l}3155 \mathrm{mg} / \mathrm{L} \\
\mathrm{TOC}, 17,312 \\
\mathrm{mg} / \mathrm{L} \text { COD }\end{array}$ & $\begin{array}{l}\mathrm{Al} \\
\mathrm{Fe}\end{array}$ & $\begin{array}{l}93 \% \text { COD } \\
92 \% \text { COD }\end{array}$ & $\begin{array}{l}60 \mathrm{~A} / \mathrm{m}^{2} \\
60 \mathrm{~A} / \mathrm{m}^{2}\end{array}$ & $\begin{array}{c}0.768 \\
\mathrm{USD} / \mathrm{m}^{3} \\
0.479 \\
\mathrm{USD} / \mathrm{m}^{3}\end{array}$ & [184] \\
\hline $\begin{array}{l}\text { Metal Removal } \\
\text { from Soil Leachate }\end{array}$ & - & $\mathrm{Fe}$ & $\begin{array}{l}99.4 \% \mathrm{Zn}^{2+} \\
99.7 \% \mathrm{pb}^{2+}\end{array}$ & $68 \mathrm{~A} / \mathrm{m}^{2}$ & $\begin{array}{l}35.38 \text { USD } \\
\text { tst- } 1\end{array}$ & [185] \\
\hline
\end{tabular}

\section{Challenges and Suggested Mitigations}

Though EC is not a new technology for wastewater treatment, most of these pollutant removal studies have been performed on a laboratory scale with pollutant centred approach. To make a feasible treatment method on the industrial level, EC technologies should be scaled-up [143]. EC scale-up has several challenges, such as deterioration of cathode performance by chemicals, anodic biofilm reduction, short-term stability, fouling, distortion of chemicals, optimization of the process, and system clogging by solid contaminants. Still, several attempts have been made to optimize the transition from bench scale to a pilot plant $[186,187]$. In addition, most of the work has been done on synthetic wastewater, which creates ideal conditions without the interference of other contaminants. For this reason, some extensive research is required using real pharmaceutical wastewater to investigate actual performance in the field and representative conditions [188].

Another problem with the EC technology is the high operating cost, including costly electrode material and electricity required [189]. Thus, future research is needed to improve anodic consumption and cathodic passivation [190]. However, this problem could be alleviated to some extent using scrap materials from the aluminium and iron industries. To compensate for the operational costs, the electric current recovery and hydrogen production possibilities are being explored. In addition, renewable sources such as windmills, solar energy, and biofuel could be used for cost-effective EC processes [191]. 
Even after several software aided optimization, the EC process parameters are not fully optimized yet [143]. In order to prove this method reliable for large-scale pharmaceutical wastewater treatment, more exhaustive studies are required in the field of pharmaceutical range and metabolic, process optimization, modelling, and scale-up. The sludge generated during the PWW treatment contains various harmful and toxic substances, which need sustainable end-use or extensive sludge management to prevent negative environmental impact. However, sludge reuse from the EC process is becoming attention in the last few years due to the presence of useful compounds such as metallic hydroxides [123].

In addition, the combination of the EC process with other technologies as pre/posttreatment might enhance the system performance. Several studies have been conducted on these combinations, such as EC adsorption [154], combined sono-EC [168,169], combined EC/chemical coagulation [161], and combined membrane/EC technologies [166]. They all observed enhanced efficiency. Therefore, future work must focus on this direction.

\section{Conclusions}

The drastic rise in pharmaceutical load in the water/wastewater has compelled researchers to investigate various treatment methods. Numerous pharmaceutical removal techniques such as advanced oxidation technology, membrane technology, bioremediation, activated carbon, and carbon nanotubes have been applied in the past. Out of these modern treatment methods, the EC treatment method is one of the best efficient methods for pharmaceutical wastewater. The simplicity in operation and ease in sludge handling also make it more persuasive. In addition, a combined EC treatment method is also possible as a pre/post treatment unit depending on the type of pollutant present, e.g., combined membrane/EC process, combined Sono/EC process, and combined EC/adsorption process. However, some constraints such as energy consumption, processing cost, and sludge handling are present. Other drawbacks such as electrode passivation and inconsistent coagulant dosing on long-period operation are also there. Still, this technology could be one of the best treatment options for pharmaceuticals after a potential advancement in process parameters.

For this reason, further investigations are required in the field of EC mechanism for the target pollutant, understanding of complex physiochemical phenomena, process parameter, possibilities of the scalable reactor, and sustainable energy sources. Different combinations of pretreatment and post-treatment with EC are more effective for various pollutants and need further investigation. Moreover, more studies are suggested in the field of pharmaceutical removal from wastewater by electrocoagulation using real wastewater.

Author Contributions: Conceptualization, methodology, investigation, writing-original draft, and review of the final manuscript: R.A., M.S. (Mohd Sheob), B.S., and S.U.K.; formal analysis: R.A. and S.U.K.; resources, supervision, and review: M.S. (Maryam Shirinkar), Z.F., F.B., and I.H.F.; visualization: R.A. and S.U.K.; review and editing: R.A., S.U.K., and Z.F.; resources and review, S.U.K. and I.H.F. All authors have read and agreed to the published version of the manuscript.

Funding: This research received no external funding.

Institutional Review Board Statement: Not applicable.

Informed Consent Statement: Not applicable.

Acknowledgments: Khan is thankful for the academic support and resources of the Department of Civil Engineering, Zakir Husain College of Engineering and Technology, Aligarh Muslim University, India.

Conflicts of Interest: The authors declare no conflict of interest.

\section{References}

1. Fatta-Kassinos, D.; Meric, S.; Nikolaou, A. Pharmaceutical residues in environmental waters and wastewater: Current state of knowledge and future research. Anal. Bioanal. Chem. 2011, 399, 251-275. [CrossRef]

2. Khan, U.; Nicell, J.A. Assessing the risk of exogenously consumed pharmaceuticals in land-applied human urine. Water Sci. Technol. 2010, 62, 1335-1345. [CrossRef] [PubMed] 
3. Lapworth, D.J.; Baran, N.; Stuart, M.E.; Ward, R.S. Emerging organic contaminants in groundwater: A review of sources, fate and occurrence. Environ. Pollut. 2012, 163, 287-303. [CrossRef] [PubMed]

4. Yang, Y.; Ok, Y.S.; Kim, K.H.; Kwon, E.E.; Tsang, Y.F. Occurrences and removal of pharmaceuticals and personal care products (PPCPs) in drinking water and water/sewage treatment plants: A review. Sci. Total Environ. 2017, 596-597, 303-320. [CrossRef] [PubMed]

5. Chander, V.; Sharma, B.; Negi, V.; Aswal, R.S.; Singh, P.; Singh, R.; Dobhal, R. Pharmaceutical Compounds in Drinking Water. J. Xenobiotics 2016, 6, 5774. [CrossRef] [PubMed]

6. Snyder, S.; Lue-Hing, C.; Cotruvo, J.; Drewes, J.E.; Eaton, A.; Pleus, R.C.; Schlenk, D. Pharmaceuticals in the Water Environment. National Association of Clean Water Environment (NACWA) and Association of Metropolitan Water Agencies (AMWA). 2009 , p. 38. Available online: https://www.acs.org/content/dam/acsorg/policy/acsonthehill/briefings/pharmaceuticalsinwater/nacwapaper.pdf (accessed on 27 May 2021).

7. Abdel-Shafy, I. Issue of Pharmaceutical Compounds in Water and Wastewater: Sources, Impact and Elimination. Egypt. J. Chem. 2013, 56, 449-471.

8. Khan, S.U.; Rameez, H.; Basheer, F.; Farooqi, I.H. Eco-toxicity and health issues associated with the pharmaceuticals in aqueous environments: A global scenario. In Pharmaceutical Wastewater Treatment Technologies: Concepts and Implementation Strategies; IWA Publishing: London, UK, 2021. [CrossRef]

9. Jukosky, J.A.; Watzin, M.C.; Leiter, J.C. The effects of environmentally relevant mixtures of estrogens on Japanese medaka (Oryzias latipes) reproduction. Aquat. Toxicol. 2008, 86, 323-331. [CrossRef] [PubMed]

10. Gross-Sorokin, M.Y.; Roast, S.D.; Brighty, G.C. Assessment of feminization of male fish in English rivers by the Environment Agency of England and Wales. Environ. Health Perspect. 2006, 114, 147-151. [CrossRef]

11. Crane, M.; Watts, C.; Boucard, T. Chronic aquatic environmental risks from exposure to human pharmaceuticals. Sci. Total Environ. 2006, 367, 23-41. [CrossRef]

12. Quinn, B.; Gagné, F.; Blaise, C. An investigation into the acute and chronic toxicity of eleven pharmaceuticals (and their solvents) found in wastewater effluent on the cnidarian, Hydra attenuata. Sci. Total Environ. 2008, 389, 306-314. [CrossRef]

13. Gaworecki, K.M.; Klaine, S.J. Behavioral and biochemical responses of hybrid striped bass during and after fluoxetine exposure. Aquat. Toxicol. 2008, 88, 207-213. [CrossRef]

14. Nentwig, G. Effects of pharmaceuticals on aquatic invertebrates. Part II: The antidepressant drug fluoxetine. Arch. Environ. Contam. Toxicol. 2007, 52, 163-170. [CrossRef] [PubMed]

15. Pomati, F.; Castiglioni, S.; Zuccato, E.; Fanelli, R.; Vigetti, D.; Rossetti, C.; Calamari, D. Effects of a complex mixture of therapeutic drugs at environmental levels on human embryonic cells. Environ. Sci. Technol. 2006, 40, 2442-2447. [CrossRef] [PubMed]

16. Emmanuel, E.; Pierre, M.G.; Perrodin, Y. Groundwater contamination by microbiological and chemical substances released from hospital wastewater: Health risk assessment for drinking water consumers. Environ. Int. 2009, 35, 718-726. [CrossRef] [PubMed]

17. Kumaraswamy, R.; Amha, Y.M.; Anwar, M.Z.; Henschel, A.; Rodríguez, J.; Ahmad, F. Molecular analysis for screening human bacterial pathogens in municipal wastewater treatment and reuse. Environ. Sci. Technol. 2014, 48, 11610-11619. [CrossRef] [PubMed]

18. Miège, C.; Choubert, J.M.; Ribeiro, L.; Eusèbe, M.; Coquery, M. Fate of pharmaceuticals and personal care products in wastewater treatment plants-conception of a database and first results. Environ. Pollut. 2009, 157, 1721-1726. [CrossRef] [PubMed]

19. Stackelberg, P.E.; Furlong, E.T.; Meyer, M.T.; Zaugg, S.D.; Henderson, A.K.; Reissman, D.B. Persistence of pharmaceutical compounds and other organic wastewater contaminants in a conventional drinking-water-treatment plant. Sci. Total Environ. 2004, 329, 99-113. [CrossRef]

20. Kümmerer, K. Drugs in the environment: Emission of drugs, diagnostic aids and disinfectants into wastewater by hospitals in relation to other sources-A review. Chemosphere 2001, 45, 957-969. [CrossRef]

21. Farhadi, S.; Aminzadeh, B.; Torabian, A.; Khatibikamal, V.; Alizadeh Fard, M. Comparison of COD removal from pharmaceutical wastewater by electrocoagulation, photoelectrocoagulation, peroxi-electrocoagulation and peroxi-photoelectrocoagulation processes. J. Hazard. Mater. 2012, 219-220, 35-42. [CrossRef]

22. Gebhardt, W.; Schröder, H.F. Liquid chromatography-(tandem) mass spectrometry for the follow-up of the elimination of persistent pharmaceuticals during wastewater treatment applying biological wastewater treatment and advanced oxidation. J. Chromatogr. 2007, 1160, 34-43. [CrossRef]

23. Klavarioti, M.; Mantzavinos, D.; Kassinos, D. Removal of residual pharmaceuticals from aqueous systems by advanced oxidation processes. Environ. Int. 2009, 35, 402-417. [CrossRef]

24. Ensano, B.M.B.; Borea, L.; Naddeo, V.; Belgiorno, V.; De Luna, M.D.G.; Ballesteros, F.C. Removal of Pharmaceuticals from Wastewater by Intermittent Electrocoagulation. Water 2017, 9, 85. [CrossRef]

25. Sanchez-Galvis, E.M.; Cardenas-Gutierrez, I.Y.; Contreras-Ropero, J.E.; García-Martínez, J.B.; Barajas-Solano, A.F.; Zuorro, A. An innovative low-cost equipment for electro-concentration of microalgal biomass. App. Sci. 2020, 10, 4841. [CrossRef]

26. Khan, S.U.; Mahtab, M.S.; Farooqi, I.H. Enhanced lead (II) removal with low energy consumption in an electrocoagulation column employing concentric electrodes: Process optimisation by RSM using CCD. Int. J. Environ. Anal. Chem. 2021, 1-18. [CrossRef]

27. Emamjomeh, M.M.; Mousazadeh, M.; Mokhtari, N.; Jamali, H.A.; Makkiabadi, M.; Naghdali, Z.; Hashim, K.S.; Ghanbari, R. Simultaneous removal of phenol and linear alkylbenzene sulfonate from automotive service station wastewater: Optimization of coupled electrochemical and physical processes. Sep. Sci. Technol. 2020, 55, 3184-3194. [CrossRef] 
28. Khetan, S.K.; Collins, T.J. Human Pharmaceuticals in the Aquatic Environment: A Challenge to Green Chemistry. Chem. Rev. 2007, 107, 2319-2364. [CrossRef]

29. Rana, R.S.; Singh, P.; Kandari, V.; Singh, R.; Dobhal, R.; Gupta, S. A review on characterization and bioremediation of pharmaceutical industries' wastewater: An Indian perspective. Appl. Water Sci. 2017, 7, 1-12. [CrossRef]

30. Rezania, S.; Park, J.; Md Din, M.F.; Mat Taib, S.; Talaiekhozani, A.; Kumar Yadav, K.; Kamyab, H. Microplastics pollution in different aquatic environments and biota: A review of recent studies. Mar. Pollut. Bull. 2018, 133, 191-208. [CrossRef] [PubMed]

31. Lübbert, C.; Baars, C.; Dayakar, A.; Lippmann, N.; Rodloff, A.C.; Kinzig, M.; Sörgel, F. Environmental pollution with antimicrobial agents from bulk drug manufacturing industries in Hyderabad, South India, is associated with dissemination of extendedspectrum beta-lactamase and carbapenemase-producing pathogens. Infection 2017, 45, 479-491. [CrossRef]

32. Fick, J.; Söderström, H.; Lindberg, R.H.; Phan, C.; Tysklind, M.; Larsson, D.G.J. Contamination of surface, ground, and drinking water from pharmaceutical production. Environ. Toxicol. Chem. 2009, 28, 2522-2527. [CrossRef]

33. Bengtsson-Palme, J.; Boulund, F.; Fick, J.; Kristiansson, E.; Larsson, D.G.J. Shotgun metagenomics reveals a wide array of antibiotic resistance genes and mobile elements in a polluted lake in India. Front. Microbiol. 2014, 5, 648. [CrossRef] [PubMed]

34. Marathe, N.; Regina, V.R.; Walujkar, S.A.; Charan, S.; Moore, E.R.B.; Joakim Larsson, D.G.; Shouche, Y.S. A treatment plant receiving waste water from multiple bulk drug manufacturers is a reservoir for highly multi-drug resistant integron-bearing bacteria. PLoS ONE 2013, 8, 77310. [CrossRef]

35. Bill. 2020. Available online: http:/ / moef.gov.in/wp-content/uploads/2019/02/silent-valley.pdf (accessed on 27 May 2021).

36. Heberer, T. Occurrence, fate, and removal of pharmaceutical residues in the aquatic environment: A review of recent research data. Toxicol. Lett. 2002, 131, 5-17. [CrossRef]

37. Martín, J.; Camacho-Muñoz, D.; Santos, J.L.; Aparicio, I.; Alonso, E. Occurrence of pharmaceutical compounds in wastewater and sludge from wastewater treatment plants: Removal and ecotoxicological impact of wastewater discharges and sludge disposal. $J$. Hazard. Mater. 2012, 239-240, 40-47. [CrossRef]

38. Liu, J.L.; Wong, M.H. Pharmaceuticals and personal care products (PPCPs): A review on environmental contamination in China. Environ. Int. 2013, 59, 208-224. [CrossRef]

39. Li, B.; Zhang, T. Biodegradation and Adsorption of Antibiotics in the Activated Sludge Process. Environ. Sci. Technol. 2010, 44, 3468-3473. [CrossRef] [PubMed]

40. Zhang, Z.; Wang, B.; Yuan, H.; Ma, R.; Huang, J.; Deng, S.; Wang, Y.; Yu, G. Discharge inventory of pharmaceuticals and personal care products in Beijing, China. Emerg. Contam. 2016, 2, 148-156. [CrossRef]

41. Hodges, J.E.N.; Holmes, C.M.; Vamshi, R.; Mao, D.; Price, O.R. Estimating chemical emissions from home and personal care products in China. Environ. Pollut. 2012, 165, 199-207. [CrossRef]

42. Robinson, I.; Junqua, G.; Van Coillie, R.; Thomas, O. Trends in the detection of pharmaceutical products, and their impact and mitigation in water and wastewater in North America. Anal. Bioanal. Chem. 2007, 387, 1143-1151. [CrossRef] [PubMed]

43. Petrovic, M.; Alda, D.; Maria, J.L.; Diaz-Cruz, S.; Postigo, C.; Radjenovic, J.; Gros, M.; Barcelo, D. Fate and removal of pharmaceuticals and illicit drugs in conventional and membrane bioreactor wastewater treatment plants and by riverbank filtration. Philos. Trans. R. Soc. A Math. Phys. Eng. Sci. 2009, 367, 3979-4003. [CrossRef]

44. Deegan, A.M.; Shaik, B.; Nolan, K.; Urell, K.; Tobin, J.; Morrissey, A. Treatment options for wastewater effluents from pharmaceutical companies. Int. J. Environ. Sci. Technol. 2011, 8, 649-666. [CrossRef]

45. Gome, A.; Upadhyay, K. Biodegradability Assessment of Pharmaceutical Wastewater Treated by Ozone. Int. Res. J. Environ. Sci. 2013, 2, 21-25.

46. Arsand, D.R.; Kummerer, K.; Martins, A.F. Removal of dexamethasone from aqueous solution and hospital wastewater by electrocoagulation. Sci. Total Environ. 2013, 443, 351-357. [CrossRef]

47. Dindas, G.B.; Caliskan, Y.; Celebi, E.E.; Tekbas, M.; Bektas, N.; Yatmaz, H.C. Treatment of pharmaceutical wastewater by combination of electrocoagulation, electro-fenton and photocatalytic oxidation processes. J. Environ. Chem. Eng. 2020, 8, 103777. [CrossRef]

48. Deshpande, A.M.; Satyanarayan, S.; Ramakant, S. Treatment of high-strength pharmaceutical wastewater by electrocoagulation combined with anaerobic process. Water Sci. Technol. 2010, 61, 463-472. [CrossRef]

49. Boroski, M.; Rodrigues, A.C.; Garcia, J.C.; Sampaio, L.C.; Nozaki, J.; Hioka, N. Combined electrocoagulation and TiO 2 photoassisted treatment applied to wastewater effluents from pharmaceutical and cosmetic industries. J. Hazard. Mater. 2009, 162, 448-454. [CrossRef]

50. Idris, M.; Kolo, M.; Garba, S.; Ismail, M. Physico-chemical analysis of pharmaceutical effluent and surface water of River Gorax in Minna, Niger State, Nigeria. Bull. Environ. Pharmacol. Life Sci. 2013, 2, 45-49.

51. Imran, H. Wastewater Monitoring of Pharmaceutical Industry. Electron. J. Environ. Agric. Food Chem. 2005, 60, 994-1004.

52. Cetecioglu, Z.; Ince, B.; Gros, M.; Rodriguez-Mozaz, S.; Barceló, D.; Ince, O.; Orhon, D. Biodegradation and reversible inhibitory impact of sulfamethoxazole on the utilization of volatile fatty acids during anaerobic treatment of pharmaceutical industry wastewater. Sci. Total Environ. 2015, 536, 667-674. [CrossRef]

53. Hu, H.; Jiang, C.; Ma, H.; Ding, L.; Geng, J.; Xu, K.; Huang, H.; Ren, H. Removal characteristics of DON in pharmaceutical wastewater and its influence on the N-nitrosodimethylamine formation potential and acute toxicity of DOM. Water Res. 2017, 109, 114-121. [CrossRef] [PubMed] 
54. Shi, X.; Ng, K.K.; Li, X.R.; Ng, H.Y. Investigation of intertidal wetland sediment as a novel inoculation source for anaerobic saline wastewater treatment. Environ. Sci. Technol. 2015, 49, 6231-6239. [CrossRef]

55. Rodriguez, E.; Campinas, M.; Acero, J.L.; Rosa, M.J. Investigating PPCP Removal from Wastewater by Powdered Activated Carbon/Ultrafiltration. Water Air Soil Pollut. 2016, 227, 177. [CrossRef]

56. Mailler, R.; Gasperi, J.; Coquet, Y.; Deshayes, S.; Zedek, S.; Cren-Olivé, C.; Cartiser, N.; Eudes, V.; Bressy, A.; Caupos, E.; et al. Study of a large scale powdered activated carbon pilot: Removals of a wide range of emerging and priority micropollutants from wastewater treatment plant effluents. Water Res. 2015, 72, 315-330. [CrossRef]

57. Saucier, C.; Adebayo, M.A.; Lima, E.C.; Cataluña, R.; Thue, P.S.; Prola, L.D.T.; Puchana-Rosero, M.J.; Machado, F.M.; Pavan, F.A.; Dotto, G.L. Microwave-assisted activated carbon from cocoa shell as adsorbent for removal of sodium diclofenac and nimesulide from aqueous effluents. J. Hazard. Mater. 2015, 289, 18-27. [CrossRef]

58. Flores-Cano, J.V.; Sánchez-Polo, M.; Messoud, J.; Velo-Gala, I.; Ocampo-Pérez, R.; Rivera-Utrilla, J. Overall adsorption rate of metronidazole, dimetridazole and diatrizoate on activated carbons prepared from coffee residues and almond shells. J. Environ. Manag. 2016, 169, 116-125. [CrossRef]

59. El-Shafey, E.S.I.; Al-Lawati, H.A.J.; Al-Hussaini, A.Y. Adsorption of fexofenadine and diphenhydramine on dehydrated and activated carbons from date palm leaflets. Chem. Ecol. 2014, 30, 765-783. [CrossRef]

60. Torrellas, S.A.; García Lovera, R.; Escalona, N.; Sepúlveda, C.; Sotelo, J.L.; García, J. Chemical-activated carbons from peach stones for the adsorption of emerging contaminants in aqueous solutions. Chem. Eng. J. 2015, 279, 788-798. [CrossRef]

61. Sheng, C.; Nnanna, A.G.A.; Liu, Y.; Vargo, J.D. Removal of Trace Pharmaceuticals from Water using coagulation and powdered activated carbon as pretreatment to ultrafiltration membrane system. Sci. Total Environ. 2016, 550, 1075-1083. [CrossRef]

62. Herrero Latorre, C.; Álvarez Méndez, J.; Barciela García, J.; García Martín, S.; Peña Crecente, R.M. Carbon nanotubes as solidphase extraction sorbents prior to atomic spectrometric determination of metal species: A review. Anal. Chim. Acta 2012, 749, 16-35. [CrossRef]

63. Tuzen, M.; Saygi, K.O.; Soylak, M. Solid phase extraction of heavy metal ions in environmental samples on multiwalled carbon nanotubes. J. Hazard. Mater. 2008, 152, 632-639. [CrossRef]

64. Mubarak, N.M.; Sahu, J.N.; Abdullah, E.C.; Jayakumar, N.S. Removal of Heavy Metals from Wastewater Using Carbon Nanotubes. Sep. Purif. Rev. 2014, 43, 311-338. [CrossRef]

65. Gong, J.L.; Wang, B.; Zeng, G.; Yang, C.; Niu, C.; Niu, Q.; Zhou, W.; Liang, Y. Removal of cationic dyes from aqueous solution using magnetic multi-wall carbon nanotube nanocomposite as adsorbent. J. Hazard. Mater. 2009, 164, 1517-1522. [CrossRef] [PubMed]

66. Yang, K.; Wu, W.; Jing, Q.; Zhu, L. Aqueous Adsorption of Aniline, Phenol, and their Substitutes by Multi-Walled Carbon Nanotubes. Environ. Sci. Technol. 2008, 42, 7931-7936. [CrossRef] [PubMed]

67. Shan, D.; Deng, S.; Zhao, T.; Yu, G.; Winglee, J.; Wiesner, M.R. Preparation of regenerable granular carbon nanotubes by a simple heating-filtration method for efficient removal of typical pharmaceuticals. Chem. Eng. J. 2016, 294, 353-361. [CrossRef]

68. Liu, Y.; Lo, S.; Liou, Y.; Hu, C. Removal of nonsteroidal anti-inflammatory drugs (NSAIDs) by electrocoagulation-flotation with a cationic surfactant. Sep. Purif. Technol. 2015, 152, 148-154. [CrossRef]

69. Akmehmet Balcioğlu, I.; Otker, M. Treatment of pharmaceutical wastewater containing antibiotics by $\mathrm{O}_{3}$ and $\mathrm{O}_{3} / \mathrm{H}_{2} \mathrm{O}_{2}$ processes. Chemosphere 2003, 50, 85-95. [CrossRef]

70. Davididou, K.; Monteagudo, J.M.; Chatzisymeon, E.; Duran, A.; Expósitob, A.J. Degradation and mineralization of antipyrine by UV-A LED photo-Fenton reaction intensified by ferrioxalate with addition of persulfate. Sep. Purif. Technol. 2017, 172, 227-235. [CrossRef]

71. Luo, S.; Wei, Z.; Spinney, R.; Zhang, Z.; Dionysiou, D.; Gao, L.; Chai, L.; Wang, D.; Xiao, R. UV direct photolysis of sulfamethoxazole and ibuprofen: An experimental and modelling study. J. Hazard. Mater. 2018, 343, 132-139. [CrossRef] [PubMed]

72. Ziylan-Yavas, A.; Ince, N.H. Single, simultaneous and sequential applications of ultrasonic frequencies for the elimination of ibuprofen in water. Ultrason. Sonochem. 2018, 40, 17-23. [CrossRef]

73. Loos, G.; Scheers, T.; Van Eyck, K.; Van Schepdael, A.; Adams, E.; der Bruggen, B.; Cabooter, D.; Dewil, R. Electrochemical oxidation of key pharmaceuticals using a boron doped diamond electrode. Sep. Purif. Technol. 2018, 195, 184-191. [CrossRef]

74. Liu, N.; Lei, Z.D.; Wang, T.; Wang, J.-J.; XD, Z.; Xu, G.; Tang, L. Radiolysis of carbamazepine aqueous solution using electron beam irradiation combining with hydrogen peroxide: Efficiency and mechanism. Chem. Eng. J. 2016, 295, 484-493. [CrossRef]

75. Adityosulindro, S.; Barthe, L.; González-Labrada, K.; Jáuregui Haza, U.J.; Delmas, H.; Julcour, C. Sonolysis and sono-Fenton oxidation for removal of ibuprofen in (waste)water. Ultrason. Sonochem. 2017, 39, 889-896. [CrossRef]

76. Kanakaraju, D.; Glass, B.D.; Oelgemöller, M. Advanced oxidation process-mediated removal of pharmaceuticals from water: A review. J. Environ. Manag. 2018, 219, 189-207. [CrossRef]

77. Misal, S.A.; Lingojwar, D.P.; Shinde, R.M.; Gawai, K.R. Purification and characterization of azoreductase from alkaliphilic strain Bacillus badius. Process. Biochem. 2011, 46, 1264-1269. [CrossRef]

78. Fernandes, J.P.; Duarte, P.; Almeida, C.M.R.; Carvalho, M.F.; Mucha, A.P. Potential of bacterial consortia obtained from different environments for bioremediation of paroxetine and bezafibrate. J. Environ. Chem. Eng. 2020, 8, 103881. [CrossRef]

79. Watkinson, A.J.; Murby, E.J.; Costanzo, S.D. Removal of antibiotics in conventional and advanced wastewater treatment: Implications for environmental discharge and wastewater recycling. Water Res. 2007, 41, 4164-4176. [CrossRef] 
80. Reif, R.; Omil, F.; Lema, J.M. Chapter 9-Removal of Pharmaceuticals by Membrane Bioreactor (MBR) Technology. In Analysis, Removal, Effects and Risk of Pharmaceuticals in the Water Cycle; Petrovic, M., Barcelo, D., Pérez, S., Eds.; Elsevier: Amsterdam, The Netherlands, 2013; Volume 62, pp. 287-317.

81. Kasonga, T.K.; Coetzee, M.A.A.; Kamika, I.; Momba, M.N.B. Assessing a co-culture fungal granule ability to remove pharmaceuticals in a sequencing batch reactor. Environ. Technol. 2020, 1-16. [CrossRef]

82. Bardi, A.; Yuan, Q.; Tigini, V.; Spina, F.; Varese, G.; Spennati, F.; Becarelli, S.; Gregorio, S.; Petroni, G.; Munz, G. Recalcitrant Compounds Removal in Raw Leachate and Synthetic Effluents Using the White-Rot Fungus. Water 2017, 9, 824. [CrossRef]

83. Das, M.P.; Bashwant, M.; Kumar, K.; Das, J. Control of pharmaceutical effluent parameters through bioremediation. J. Chem. Pharm. Res. 2012, 4, 1061-1065.

84. Radjenovic, J.; Petrovic, M.; Barceló, D. Analysis of pharmaceuticals in wastewater and removal using a membrane bioreactor. Anal. Bioanal. Chem. 2007, 387, 1365-1377. [CrossRef] [PubMed]

85. Giwa, A.; Hasan, S.W.; Yousuf, A.; Chakraborty, S.; Johnson, D.J.; Hilal, N. Biomimetic membranes: A critical review of recent progress. Desalination 2017, 420, 403-424. [CrossRef]

86. Shekarian, E.; Saljoughi, E.; Naderi, A. Polyacrylonitrile (PAN)/IGEPAL blend asymmetric membranes: Preparation, morphology, and performance. J. Polym. Res. 2013, 20, 162. [CrossRef]

87. Zazouli, M.A.; Susanto, H.; Nasseri, S.; Ulbricht, M. Influences of solution chemistry and polymeric natural organic matter on the removal of aquatic pharmaceutical residuals by nanofiltration. Water Res. 2009, 43, 3270-3280. [CrossRef]

88. Yoon, Y.; Westerhoff, P.; Snyder, S.A.; Wert, E.C. Removal of endocrine disrupting compounds and pharmaceuticals by nanofiltration and ultrafiltration membranes. Desalination 2007, 202, 16-23. [CrossRef]

89. Javier Benitez, F.; Acero, J.L.; Real, F.J.; Roldán, G.; Rodriguez, E. Ultrafiltration and nanofiltration membranes applied to the removal of the pharmaceuticals amoxicillin, naproxen, metoprolol and phenacetin from water. J. Chem. Technol. Biotechnol. 2011, 86, 858-866. [CrossRef]

90. Sun, S.P.; Hatton, T.A.; Chan, S.Y.; Chung, T.S. Novel thin-film composite nanofiltration hollow fiber membranes with double repulsion for effective removal of emerging organic matters from water. J. Membr. Sci. 2012, 401-402, 152-162. [CrossRef]

91. Omidvar, M.; mahmoud Mousavi, S.; Soltanieh, M.; Safekordi, A.A. Preparation and characterization of poly (ethersulfone) nanofiltration membranes for amoxicillin removal from contaminated water. J. Environ. Heal. Sci. Eng. 2014, 12, 18. [CrossRef]

92. Snyder, S.A.; Adham, S.; Redding, A.M.; Cannon, F.S.; DeCarolis, J.; Oppenheimer, J.; Wert, E.C.; Yoon, Y. Role of membranes and activated carbon in the removal of endocrine disruptors and pharmaceuticals. Desalination 2007, 202, 156-181. [CrossRef]

93. Ghernaout, D. Advanced oxidation phenomena in electrocoagulation process: A myth or a reality? Desalin. Water Treat. 2013, 51, 40-42. [CrossRef]

94. Ghernaout, D.; Irki, S.; Boucherit, A. Removal of $\mathrm{Cu}^{2+}$ and $\mathrm{Cd}^{2+}$, and humic acid and phenol by electrocoagulation using iron electrodes. Desalin. Water Treat. 2014, 52, 3256-3270. [CrossRef]

95. Yasri, N.; Hu, J.; Kibria, M.G.; Roberts, E.P.L. Electrocoagulation Separation Processes. Multidiscip. Adv. Effic. Sep. Process. 2020, 1348, 167-203.

96. Ghernaout, D.; Benblidia, C.; Khemici, F. Microalgae removal from Ghrib Dam (Ain Defla, Algeria) water by electroflotation using stainless steel electrodes. Desalin. Water Treat. 2015, 54, 3328-3337. [CrossRef]

97. Ghernaout, D. Electrocoagulation as a Pioneering Separation Technology-Electric Field Role. Green Sustain. Chem. 2020, 7, 1-19. [CrossRef]

98. Kobya, M.; Can, O.T.; Bayramoglu, M. Treatment of textile wastewaters by electrocoagulation using iron and aluminum electrodes. J. Hazard. Mater. 2003, 100, 163-178. [CrossRef]

99. Hakizimana, J.N.; Gourich, B.; Chafi, M.; Stiriba, Y.; Vial, C.; Drogui, P.; Naja, J. Electrocoagulation process in water treatment: A review of electrocoagulation modeling approaches. Desalination 2017, 404, 1-21. [CrossRef]

100. Ghernaout, D.; Elboughdiri, N. Dealing with Cyanobacteria and Cyanotoxins: Engineering Viewpoints. Open Access Libr. J. 2020, 7, 1. [CrossRef]

101. Ghernaout, D.; Elboughdiri, N. Eliminating Cyanobacteria and Controlling Algal Organic Matter-Short Notes. Open Access Libr. J. 2020, 7, 1-17. [CrossRef]

102. Mousazadeh, M.; Alizadeh, S.M.; Frontistis, Z.; Kabdaşlı, I.; Karamati Niaragh, E.; Al Qodah, Z.; Naghdali, Z.; Mahmoud, A.E.; Sandoval, M.A.; Butler, E.; et al. Electrocoagulation as a Promising Defluoridation Technology from Water: A Review of State of the Art of Removal Mechanisms and Performance Trends. Water 2021, 13, 656. [CrossRef]

103. Faheem, K.; Khan, S.U.; Washeem, M.; Khan, S.U. Energy efficient removal of COD from landfill leachate wastewater using electrocoagulation: Parametric optimization using RSM. Int. J. Environ. Sci. Technol. 2021, 1-12. [CrossRef]

104. Den, W.; Chia-Jung, W. Removal of silica from brackish water by electrocoagulation pretreatment to prevent fouling of reverse osmosis membranes. Sep. Purif. Technol. 2008, 59, 318-325. [CrossRef]

105. Hu, C.Y.; Lo, S.L.; Kuan, W.H. Simulation the kinetics of fluoride removal by electrocoagulation (EC) process using aluminum electrodes. J. Hazard. Mater. 2007, 145, 180-185. [CrossRef]

106. Bagga, A.; Chellam, S.; Clifford, D.C. Evaluation of iron chemical coagulation and electrocoagulation pretreatment for surface water microfiltration. J. Memb. Sci. 2008, 309, 82-93. [CrossRef]

107. Gu, Z.; Liao, Z.; Schulz, M.; Davis, J.R.; Baygents, J.C.; Farrell, J. Estimating Dosing Rates and Energy Consumption for Electrocoagulation Using Iron and Aluminum Electrodes. Ind. Eng. Chem. Res. 2009, 48, 3112-3117. [CrossRef] 
108. Mansouri, K.; Ibrik, K.; Bensalah, N.; Abdel-Wahab, A. Anodic Dissolution of Pure Aluminum during Electrocoagulation Process: Influence of Supporting Electrolyte, Initial pH, and Current Density. Ind. Eng. Chem. Res. 2011, 50, 13362-13372. [CrossRef]

109. Rebhun, M.; Lurie, M. Control of Organic Matter by Coagulation and Floc Separation. Water Sci. Technol. 1993, 27, 1-20. [CrossRef]

110. Djuricic, T.; Malinovic, B.; Bjelić, D. The phosphate removal efficiency electrocoagulation wastewater using iron and aluminum electrodes. Bull. Chem. Technol. Bosnia Herzeg. 2017, 47, 33-38.

111. Vepsäläinen, M.; Selin, J.; Rantala, P.; Pulliainen, M.; Särkkä, H.; Kuhmonen, K.; Bhatnagar, A.; Sillanpää, M. Precipitation of dissolved sulphide in pulp and paper mill wastewater by electrocoagulation. Environ. Technol. 2011, 32, 1393-1400. [CrossRef]

112. Ferreira, A.D.; Marchesiello, M.; Thivel, P.X. Removal of copper, zinc and nickel present in natural water containing $\mathrm{Ca}^{2+}$ and $\mathrm{HCO}_{3}{ }^{-}$ions by electrocoagulation. Sep. Purif. Technol. 2013, 107, 109-117. [CrossRef]

113. Zhu, J.; Zhao, H.; Ni, J. Fluoride distribution in electrocoagulation defluoridation process. Sep. Purif. Technol. 2007, 56, 184-191. [CrossRef]

114. Khan, S.U.; Farooqi, I.H.; Usman, M.; Basheer, F. Energy Efficient Rapid Removal of Arsenic in an Electrocoagulation Reactor with Hybrid Fe/Al Electrodes: Process Optimization Using CCD and Kinetic Modeling. Water 2020, 12, 10. [CrossRef]

115. Hu, C.Y.; Lo, S.L.; Kuan, W.H. Effects of co-existing anions on fluoride removal in electrocoagulation (EC) process using aluminum electrodes. Water Res. 2003, 37, 4513-4523. [CrossRef]

116. Ben Sasson, M.; Calmano, W.; Adin, A. Iron-oxidation processes in an electroflocculation (electrocoagulation) cell. J. Hazard. Mater. 2009, 171, 704-709. [CrossRef]

117. Jimenez, C.; Saez, C.; Martinez, F.; Canizares, P.; Rodrigo, M.A. Electrochemical dosing of iron and aluminum in continuous processes: A key step to explain electro-coagulation processes. Sep. Purif. Technol. 2012, 98, 102-108. [CrossRef]

118. Malakootian, M.; Mansoorian, H.J.; Moosazadeh, M. Performance evaluation of electrocoagulation process using iron-rod electrodes for removing hardness from drinking water. Desalination 2010, 255, 67-71. [CrossRef]

119. Lakshmanan, D.; Clifford, D.A.; Samanta, G. Ferrous and Ferric Ion Generation During Iron Electrocoagulation. Environ. Sci. Technol. 2009, 43, 3853-3859. [CrossRef] [PubMed]

120. Akyol, A. Treatment of paint manufacturing wastewater by electrocoagulation. Desalination 2012, 285, 91-99. [CrossRef]

121. Kobya, M.; Senturk, E.; Bayramoglu, M. Treatment of poultry slaughterhouse wastewaters by electrocoagulation. J. Hazard. Mater. 2006, 133, 172-176. [CrossRef] [PubMed]

122. Parga, J.R.; Cocke, D.L.; Valenzuela, J.L.; Gomes, J.A.; Kesmez, M.; Irwin, G.; Moreno, H.; Weir, M. Arsenic removal via electrocoagulation from heavy metal contaminated groundwater in La Comarca Lagunera México. J. Hazard. Mater. 2005, 124, 247-254. [CrossRef] [PubMed]

123. Al-Shannag, M.; Al-Qodah, Z.; Bani-Melhem, K.; Qtai shat, M.R.; Alkasrawi, M. Heavy metal ions removal from metal plating wastewater using electrocoagulation: Kinetic study and process performance. Chem. Eng. J. 2015, 260, 749-756. [CrossRef]

124. Bensadok, K.; Benammar, S.; Lapicque, F.; Nezzal, G. Electrocoagulation of cutting oil emulsions using aluminium plate electrodes. J. Hazard. Mater. 2008, 152, 423-430. [CrossRef] [PubMed]

125. Mouedhen, G.; Feki, M.; Wery, M.D.P.; Ayedi, H.F. Behavior of aluminum electrodes in electrocoagulation process. J. Hazard. Mater. 2008, 150, 124-135. [CrossRef] [PubMed]

126. Ouaissa, Y.A.; Chabani, M.; Amrane, A.; Bensmaili, A. Removal of tetracycline by electrocoagulation: Kinetic and isotherm modeling through adsorption. J. Environ. Chem. Eng. 2014, 2, 177-184. [CrossRef]

127. Asaithambi, P.; Aziz, A.R.A.; Daud, W.M.A.B.W. Integrated ozone-electrocoagulation process for the removal of pollutant from industrial effluent: Optimization through response surface methodology. Chem. Eng. Process. Process. Intensif. 2016, 105, 92-102. [CrossRef]

128. Al-Qodah, Z.; Al-Shannag, M. Heavy metal ions removal from wastewater using electrocoagulation processes: A comprehensive review. Sep. Sci. Technol. 2017, 52, 2649-2676. [CrossRef]

129. Kobya, M.; Hiz, H.; Senturk, E.; Aydiner, C.; Demirbas, E. Treatment of potato chips manufacturing wastewater by electrocoagulation. Desalination 2006, 190, 201-211. [CrossRef]

130. Kobya, M.; Delipinar, S. Treatment of the baker's yeast wastewater by electrocoagulation. J. Hazard. Mater. 2008, 154, 1133-1140. [CrossRef]

131. Amrose, S.E.; Bandaru, S.R.S.; Delaire, C.; van Genuchten, C.M.; Dutta, A.; DebSarkar, A.; Orr, C.; Roy, J.; Das, A.; Gadgil, A.J. Electro-chemical arsenic remediation: Field trials in West Bengal. Sci. Total Environ. 2014, 488-489, 539-546. [CrossRef]

132. Essadki, A.H.; Bennajah, M.; Gourich, B.; Vial, C.; Azzi, C.; Delmas, H. Electrocoagulation/electroflotation in an external-loop airlift reactor-Application to the decolorization of textile dye wastewater: A case study. Chem. Eng. Process. Process. Intensif. 2008, 47, 1211-1223. [CrossRef]

133. Kobya, M.; Demirbas, E.; Ulu, F. Evaluation of operating parameters with respect to charge loading on the removal efficiency of arsenic from potable water by electrocoagulation. J. Environ. Chem. Eng. 2016, 4, 1484-1494. [CrossRef]

134. Nariyan, E.; Aghababaei, A.; Sillanpää, M. Removal of pharmaceutical from water with an electrocoagulation process; effect of various parameters and studies of isotherm and kinetic. Sep. Purif. Technol. 2017, 188, 266-281. [CrossRef]

135. Ensano, B.M.B.; Borea, L.; Naddeo, V.; Belgiorno, V.; de Luna, M.D.G.; Balakrishnan, M.; Ballesteros, F.C., Jr. Applicability of the electrocoagulation process in treating real municipal wastewater containing pharmaceutical active compounds. J. Hazard. Mater. 2019, 361, 367-373. [CrossRef] [PubMed] 
136. Sahu, O.; Mazumdar, B.; Chaudhari, P.K. Treatment of wastewater by electrocoagulation: A review. Environ. Sci. Pollut. Res. Int. 2014, 21, 2397-2413. [CrossRef]

137. Burns, S.E.; Yiacoumi, S.; Tsouris, C. Microbubble generation for environmental and industrial separations. Sep. Purif. Technol. 1997, 11, 221-232. [CrossRef]

138. Adhoum, N.; Monser, L. Decolourization and removal of phenolic compounds from olive mill wastewater by electrocoagulation. Chem. Eng. Process. Process. Intensif. 2004, 43, 1281-1287. [CrossRef]

139. Daneshvar, N.; Sorkhabi, H.A.; Kasiri, M.B. Decolorization of dye solution containing Acid Red 14 by electrocoagulation with a comparative investigation of different electrode connections. J. Hazard. Mater. 2004, 112, 55-62. [CrossRef] [PubMed]

140. Nasrullah, M.; Singh, L.; Wahid, Z.A. Treatment of sewage by electrocoagulation and the effect of high current density Treatment of Sewage by Electrocoagulation and the Effect of High Current Density. Energy Environ. Eng. J. 2017, 1, 27-31.

141. Khandegar, V.; Saroha, A.K. Electrocoagulation for the treatment of textile industry effluent-A review. J. Environ. Manag. 2013, 128, 949-963. [CrossRef]

142. Mollah, M.Y.A.; Morkovsky, P.; Gomes, J.A.G.; Kesmez, M.; Parga, J.; Cocke, D.L. Fundamentals, present and future perspectives of electrocoagulation. J. Hazard. Mater. 2004, 114, 199-210. [CrossRef]

143. Moussa, D.T.; El-Naas, M.H.; Nasser, M.; Al-Marri, M.J. A comprehensive review of electrocoagulation for water treatment: Potentials and challenges. J. Environ. Manag. 2017, 186, 24-41. [CrossRef]

144. Demirci, Y.; Pekel, L.C.; Alpbaz, M. Investigation of Different Electrode Connections in Electrocoagulation of Textile Wastewater Treatment. Int. J. Electrochem. Sci. 2015, 10, 2685-2693.

145. Fouad, Y.O.A.; Konsowa, A.H.; Farag, H.A.; Sedahmed, G.H. Performance of an electrocoagulation cell with horizontally oriented electrodes in oil separation compared to a cell with vertical electrodes. Chem. Eng. J. 2009, 145, 436-440. [CrossRef]

146. Tachamango, S.R.; Darchen, A. Investigation and optimization of a new electrocoagulation reactor with horizontal bipolar electrodes: Effect of electrode structure on the reactor performances. J. Environ. Chem. Eng. 2018, 6, 4546-4554. [CrossRef]

147. Kuroda, Y.; Kawada, Y.; Takahashi, T.; Ehara, Y.; Ito, T.; Zukeran, A.; Kono, Y.; Yasumoto, K. Effect of electrode shape on discharge current and performance with barrier discharge type electrostatic precipitaor. J. Electrostat. 2003, 57, 407-415. [CrossRef]

148. Ahmadzadeh, S.; Asadipour, A.; Pournamdari, M.; Behnam, B.; Rahimi, H.R.; Dolatabadi, M. Removal of ciprofloxacin from hospital wastewater using electrocoagulation technique by aluminum electrode: Optimization and modelling through response surface methodology. Process. Saf. Environ. Prot. 2017, 109, 538-547. [CrossRef]

149. Mohora, E.; Rončević, S.; Agbaba, J.; Tubić, A.; Mitić, M.; Klašnja, M.; Dalmacija, B. Removal of arsenic from groundwater rich in natural organic matter (NOM) by continuous electrocoagulation/flocculation (ECF). Sep. Purif. Technol. 2014, 136, 150-156. [CrossRef]

150. Sharma, D.; Chaudhari, P.K.; Prajapati, A.K. Removal of chromium (VI) and lead from electroplating effluent using electrocoagulation. Sep. Sci. Technol. 2020, 55, 321-331. [CrossRef]

151. Bao, J.; Yu, W.J.; Liu, Y.; Wang, X.; Liu, Z.Q.; Duan, Y.F. Removal of perfluoroalkanesulfonic acids (PFSAs) from synthetic and natural groundwater by electrocoagulation. Chemosphere 2020, 248, 125951. [CrossRef] [PubMed]

152. Castellaños-Estupiñana, M.A.; Sánchez-Galvisa, E.M.; García-Martínezb, J.B.; Barajas-Ferreirab, C.; Zuorroc, A.; Barajas-Solano, A.F. Design of an electroflotation system for the concentration and harvesting of freshwater microalgae. Chem. Eng. $2018,64$. [CrossRef]

153. Linares-Hernández, I.; Barrera-Díaz, C.; Roa-Morales, G.; Bilyeu, B.; Ureña-Núñez, F. A combined electrocoagulation-sorption process applied to mixed industrial wastewater. J. Hazard. Mater. 2007, 144, 240-248. [CrossRef] [PubMed]

154. Aouni, A.; Lafi, R.; Hafiane, A. Feasibility evaluation of combined electrocoagulation/adsorption process by optimizing operating parameters removal for textile wastewater treatment. Desalin. Water Treat. 2017, 60, 78-87. [CrossRef]

155. Shamaei, L.; Khorshidi, B.; Perdicakis, B.; Sadrzadeh, B. Treatment of oil sands produced water using combined electrocoagulation and chemical coagulation techniques. Sci. Total Environ. 2018, 645, 560-572. [CrossRef]

156. Radić, S.; Vujčić, V.; Cvetković, Z.; Cvjetko, P.; Oreščanin, V. The efficiency of combined CaO/electrochemical treatment in removal of acid mine drainage induced toxicity and genotoxicity. Sci. Total Environ. 2014, 466-467, 84-89. [CrossRef]

157. Can, O.T.; Kobya, M.; Demirbas, E.; Bayramoglu, M. Treatment of the textile wastewater by combined electrocoagulation. Chemosphere 2006, 62, 181-187. [CrossRef]

158. Salih Muharam, S.M.; Rahmah, C.I.; Yuningsih, L.M. Simultaneous Combination of Electrocoagulation and Chemical Coagulation Methods for Medical Wastewater Treatment. Makara J. Sci. 2017, 21, 113-118.

159. Kermet-Said, H.; Moulai-Mostefa, N. Optimization of Turbidity and COD Removal from Pharmaceutical Wastewater by Electrocoagulation. Isotherm Modeling and Cost Analysis. Pol. J. Environ. Stud. 2015, 24, 1049-1061.

160. Oulebsir, A.; Chaabane, T.; Tounsi, H.; Omine, K.; Sivasankar, V.; Flilissa, A.; Darchen, A. Treatment of artificial pharmaceutical wastewater containing amoxicillin by a sequential electrocoagulation with calcium salt followed by nanofiltration. J. Environ. Chem. Eng. 2020, 8, 104597. [CrossRef]

161. Padmaja, K.; Cherukuri, J.; Reddy, M.A. A comparative study of the efficiency of chemical coagulation and electrocoagulation methods in the treatment of pharmaceutical effluent. J. Water Process. Eng. 2020, 34, 101153. [CrossRef]

162. Balark, D.; Chandrika, K.; Attaolahi, M. Assessment of Effective Operational Parameters on Removal of Amoxicillin from Synthetic Wastewater Using Electrocoagulation Process. J. Pharm. Res. Int. 2019. [CrossRef] 
163. Ren, M.; Song, Y.; Xiao, S.; Zeng, P.; Peng, J. Treatment of berberine hydrochloride wastewater by using pulse electro-coagulation process with Fe electrode. Chem. Eng. J. 2011, 169, 84-90. [CrossRef]

164. Al-qodah, Z.; Tawalbeh, M.; Al-shannag, M.; Al-anber, Z.; Bani-Melhem, K. Combined electrocoagulation processes as a novel approach for enhanced pollutants removal: A state-of-the-art review. Sci. Total Environ. 2020, 744, 140806. [CrossRef]

165. Hakizimana, J.N.; Gourich, B.; Vial, C.; Drogui, P.; Oumani, A.; Naja, J.; Hilali, L. Assessment of hardness, microorganism and organic matter removal from seawater by electrocoagulation as a pretreatment of desalination by reverse osmosis. Desalination 2016, 393, 90-101. [CrossRef]

166. Sardari, K.; Fyfe, P.; Wickramasinghe, S.R. Integrated electrocoagulation-Forward osmosis-Membrane distillation for sustainable water recovery from hydraulic fracturing produced water. J. Membr. Sci. 2018, 574, 325-337. [CrossRef]

167. Asaithambi, P.; Aziz, A.R.A.; Sajjadi, B.; Daud, W.M.A.B.W. Sono assisted electrocoagulation process for the removal of pollutant from pulp and paper industry effluent. Environ. Sci. Pollut. Res. 2017, 24, 5168-5178. [CrossRef]

168. Maha Lakshmi, P.; Sivashanmugam, P. Treatment of oil tanning effluent by electrocoagulation: Influence of ultrasound and hybrid electrode on COD removal. Sep. Purif. Technol. 2013, 116, 378-384. [CrossRef]

169. Raschitor, A.; Fernandez, C.M.; Cretescu, I.; Rodrigo, M.A.; Cañizares, P. Sono-electrocoagulation of wastewater polluted with Rhodamine 6G. Sep. Purif. Technol. 2014, 135, 110-116. [CrossRef]

170. Asaithambi, P. Studies on various operating parameters for the removal of COD from pulp and paper industry using electrocoagulation process. Desalin. Water Treat. 2016, 57, 11746-11755. [CrossRef]

171. Mousazadeh, M.; Niaragh, E.K.; Usman, M.; Khan, S.U.; Sandoval, M.A.; Al-Qodah, Z.; Khalid, B.K.; Gilhotra, V.; Emamjomeh, M.M. A critical review of state-of-the-art electrocoagulation technique applied to COD-rich industrial wastewaters. Environ. Sci. Pollut. Res. 2021, 1-30. [CrossRef]

172. Khan, S.U.; Asif, M.; Alam, F.; Khan, N.A.; Farooqi, I.H. Optimizing fluoride removal and energy consumption in a batch reactor using electrocoagulation: A smart treatment technology. In Smart Cities-Opportunities and Challenges; Springer: Singapore, 2020; pp. 767-778.

173. Ilhan, F.; Kurt, U.; Apaydin, O.; Gonullu, M.T. Treatment of leachate by electrocoagulation using aluminum and iron electrodes. J. Hazard. Mater. 2008, 154, 381-389. [CrossRef]

174. Kobya, M.; Bayramoglu, M.; Eyvaz, M. Techno-economical evaluation of electrocoagulation for the textile wastewater using different electrode connections. J. Hazard. Mater. 2007, 148, 311-318. [CrossRef]

175. Khan, S.U.; Islam, D.T.; Farooqi, I.H.; Ayub, S.; Basheer, F. Hexavalent chromium removal in an electrocoagulation column reactor: Process optimization using CCD, adsorption kinetics and pH modulated sludge formation. Process. Saf. Environ. Prot. 2019, 122, 118-130. [CrossRef]

176. Kobya, M.; Demirbas, E.; Bayramoglu, M.; Sensoy, M.T. Optimization of Electrocoagulation Process for the Treatment of Metal Cutting Wastewaters with Response Surface Methodology. Water Air Soil Pollut. 2011, 215, 399-410. [CrossRef]

177. Espinoza-Quiñones, F.R.; Fornari, M.M.T.; Módenes, A.N.; Palácio, S.M.; Fernando, G.; da Silva, F.G., Jr.; Szymanski, N.; Kroumov, A.D.; Trigueros, D.E.G. Pollutant removal from tannery effluent by electrocoagulation. Chem. Eng. J. 2009, 151, 59-65. [CrossRef]

178. Khaled, B.; Wided, B.; Béchir, H.; Elimame, E.; Mouna, L.; Zied, T. Investigation of electrocoagulation reactor design parameters effect on the removal of cadmium from synthetic and phosphate industrial wastewater. Arab. J. Chem. 2019, 12, 1848-1859. [CrossRef]

179. Merzouk, B.; Gourich, B.; Madani, K.; Vial, C.; Sekki, A. Removal of a disperse red dye from synthetic wastewater by chemical coagulation and continuous electrocoagulation. A comparative study. Desalination 2011, 272, 246-253. [CrossRef]

180. Chafi, M.; Gourich, B.; Essadki, A.H.; Vial, C.; Fabregat, A. Comparison of electrocoagulation using iron and aluminium electrodes with chemical coagulation for the removal of a highly soluble acid dye. Desalination 2011, 281, 285-292. [CrossRef]

181. Oncel, M.S.; Muhcu, A.; Demirbas, E.; Kobya, M. A comparative study of chemical precipitation and electrocoagulation for treatment of coal acid drainage wastewater. J. Environ. Chem. Eng. 2013, 1, 989-995. [CrossRef]

182. Bayramoglu, M.; Kobya, M.; Can, O.T.; Sozbir, M. Operating cost analysis of electrocoagulation of textile dye wastewater. Sep. Purif. Technol. 2004, 37, 117-125. [CrossRef]

183. Bayramoglu, M.; Eyvaz, M.; Kobya, M. Treatment of the textile wastewater by electrocoagulation: Economical evaluation. Chem. Eng. J. 2007, 128, 155-161. [CrossRef]

184. Kobya, M.; Ciftci, C.; Bayramoglu, C.; Sensoy, M.T. Study on the treatment of waste metal cutting fluids using electrocoagulation. Sep. Purif. Technol. 2008, 60, 285-291. [CrossRef]

185. Drogui, P.; Meunier, N.; Mercier, G.; Blais, J.F. Removal of $\mathrm{Pb}^{2+}$ and $\mathrm{Zn}^{2+}$ ions from acidic soil leachate: A comparative study between electrocoagulation, adsorption and chem. Int. J. Environ. Waste Manag. 2011, 8, 241-257. [CrossRef]

186. Walter, D.; Chihpin, H. Electrocoagulation of Silica Nanoparticles in Wafer Polishing Wastewater by a Multichannel Flow Reactor: A Kinetic Study. J. Environ. Eng. 2006, 132, 1651-1658.

187. Calvo, L.S.; Leclerc, J.P.; Tanguy, G.; Cames, M.C.; Paternotte, G.; Valentin, G.; Rostan, A.; Lapicque, F. An electrocoagulation unit for the purification of soluble oil wastes of high COD. Environ. Prog. 2003, 22, 57-65. [CrossRef]

188. Pulkka, S.; Martikainen, M.; Bhatnagar, A.; Sillanpaa, M. Electrochemical methods for the removal of anionic contaminants from water-A review. Sep. Purif. Technol. 2014, 132, 252-271. [CrossRef] 
189. Mateen, Q.S.; Khan, S.U.; Islam, D.T.; Khan, N.A.; Farooqi, I.H. Copper (II) removal in a column reactor using electrocoagulation: Parametric optimization by response surface methodology using central composite design. Water Environ. Res. 2020, 92, 1350-1362. [PubMed]

190. Fernandes, A.; Chamem, O.; Pacheco, M.J.; Ciríaco, L.; Zairi, M.; Lopes, A. Performance of Electrochemical Processes in the Treatment of Reverse Osmosis Concentrates of Sanitary Landfill Leachate. Molecules 2019, 24, 2905. [CrossRef] [PubMed]

191. Dominguez-Ramos, A.; Aldaco, R.; Irabien, A. Photovoltaic solar electrochemical oxidation (PSEO) for treatment of lignosulfonate wastewater. J. Chem. Technol. Biotechnol. 2010, 85, 821-830. [CrossRef] 